\title{
DISCLAIMER
}

This report was prepared as an account of work sponsored by an agency of the United States Government nor any agency thereof, nor any of their Government. Neither the United States Goverimplied, or assumes any legal liability or responsiemployees, makes any warranty, express or implied, or ass information, apparatus, product, or bility for the accuracy, completeness, or usefulness of any inorivately owned rights. Referprocess disclosed, or represents that its use would not in, or service by trade name, trademark, ence herein to any specific commercial product, process, or se imply its endorsement, recommanufacturer, or otherwise does not necessarily conernment or any agency thereof. The views mendation, or favoring by the United States Goven necessarily state or reflect those of the and opinions of authors expressed herein do not

United States Government or any agency thereof.

\section{TECHNOLOGICAL IMPLICATIONS OF SNAP REACTOR \\ POWER SYSTEM DEVELOPMENT ON FUTURE SPACE \\ NUCLEAR POWER SYSTEMS}

By

R. V. Anderson

Program Development Manager

Advanced Systems

Energy Systems Group

Rockwell International

PORTIONS OF THIS REPORT ARE ILLEGIBLE.

It has been reproduced from the best available copy to permit the broadest possible availability.

\section{Rockwell International}




\section{DISCLAIMER}

This report was prepared as an account of work sponsored by an agency of the United States Government. Neither the United States Government nor any agency Thereof, nor any of their employees, makes any warranty, express or implied, or assumes any legal liability or responsibility for the accuracy, completeness, or usefulness of any information, apparatus, product, or process disclosed, or represents that its use would not infringe privately owned rights. Reference herein to any specific commercial product, process, or service by trade name, trademark, manufacturer, or otherwise does not necessarily constitute or imply its endorsement, recommendation, or favoring by the United States Government or any agency thereof. The views and opinions of authors expressed herein do not necessarily state or reflect those of the United States Government or any agency thereof. 


\section{DISCLAIMER}

Portions of this document may be illegible in electronic image products. Images are produced from the best available original document. 


\section{TECHNOLOGICAL IMPLICATIONS OF SNAP REACTOR POWER SYSTEN DEVELOPMENT ON FUTURE SPACE \\ NUCLEAR POWER SYSTENS}

By

R. V. Anderson

Program Development Manager

Advanced Systems

Energy Systems Group

Rockwell International

Canoga Park, California

\section{Abstract}

A7though the Space Transportation System brings a new era to United States space technology, the U.S. still lags the U.S.S.R. in total space launches per year and in the development of nuclear systems for higher electric powers in space. The power levels for future U.S. military and civilian space missions are not fully defined at this time; however, power needs can easily be projected to much higher values than required today. Nuclear reactor systems are one method of satisfying these power needs. The development of such systems must proceed on a path consistent with mission needs and schedules. This path, or technology roadmap, starts from the power systen technology data base available today. Much of this data base was established during the 1960s and early 1970s, when government and industry cleveloped space nuclear reactor systems for steady-state power and propulsion. One of the largest development programs was the Systems for Nuclear Auxiliary Power (SNAP) Program. By the early 1970s, a technology base had 
evolved from this program at the system, subsystem, and component levels. There are many implications of this technology base on future reactor power systems. A review of this base highlights the need for performing a power system technology and mission overview study. Such a study is currently being performed by Rockwell's Energy Systems Group for the Department of Energy and will assess power system capabilities versus mission needs, considering development, schedule, and cost implications. The end product of the study will be a technology roadmap to guide reactor power system development.

\section{Introduction}

With the advent of the Space Shuttle, the 1980s bring a new era to United States space technology. The Space Shuttle is ultimately capable of lifting 30-metric-ton payloads into low-earth orbits (Figure 1). Not only is the shuttle a reusable launch vehicle, but a viable space experimental laboratory. Using sortie missions, experiments can be launched, carried out in the

environment of space, and recovered (Figure 2). The total Space Transportation System (STS) will eventually encompass upper stages for placement of missions into higher altitude and geosynchronous equatorial orbits (Figure 3 ).

The 1980s, however, also pose a different perspective for the United States in its role as military and technology leader of the world. Even with the advancements in launch capability, our chief political competitor, the 
U.S.S.R., has "out launched" the United States, 88 launches to 12 through the first 10 months of 1982. Of the U.S.S.R.'s 88 launches, 71 were for military purposes, compared to only three of the U.S.'S 12 launches.

On the other hand, the United States' Teadership in military technology became apparent during the Lebanon war of 1982. This war focused on Western war-fighting technology and demonstrated the superiority of this technology over that supplied by the U.S.S.R. to its allies. The bottom line is that U.S.S.R. capabilities tend to exceed U.S. capabilities in quantity, but not in quality.

One technology area where the U.S.S.R. has succeeded in toth quantity and quality is the development of space nuclear reactor power systems. Seventeen years ago, the U.S. launched a single space reactor power system called the SNAP-1OA (Figure 4). This system, launched in a spacecraft called SNAPSHOT in 1965, was a flight qualification system developed for the Atomic Energy Commission and the Air Force by Atomics International (now a division of Rockwell's Energy Systems Group). It is interesting to note that the original Soviet space reactor power system, called "ROMASHKA," was a derivative of a very early static SNAP-10 concept (Figure 5). Since the SNAPSHOT launch in 1965, the Soviets have improved the quality of their space nuclear reactor power capabilities through a thermionic system called "TOPAZ." A derivative of the ROMASHKA and TOPAZ systems provides power for the ir Radar Ocean Reconnaissance Satellites (RORSATs) (Figure 6). Approximately 20 RORSATs have been 
launched by the Soviets, with four launches in the first 10 months of 1982 . Although the RORSAT nuclear power system is neither high powered nor long lived, the Soviet use of reactors exemplifies their belief that power requirements for space will increase over time.

For the U.S., these increasing power requirements will come from military missions (surveillance and war-fighting) and also from civilian missions (scientific and large commercial). The real power system needs for these missions can only be estimated at this time. To assess these needs, two parameters in addition to power must be evaluated. These are the duration of the power and the mass of the system providing the power. The product of the power and its duration is the energy output of the system, and both the power and energy affect the system mass. The mass in turn affects the total launch requirements for the mission. For the types of missions being discussed by military and civilian planners today, ranges on power, power duration, and power system mass can be defined and interrelated. Power requirements range over 4 decades, from $10 \mathrm{kWe}$ to 100 MWe. Power duration requirements range over 6 decades, from seconds of semicontinuous power for directed energy applications to near 100,000 hours for long-lived, steady-state applications. System mass requirements range over 3 decades, from hundreds of kilograms to tens of thousands of kilograms. When plotted in a three-dimensional log-loglog coordinate system, the interrelation of these three parameters defines a "requirements" space (Figure 7). Examining this space, the difference between steady-state and semicontinuous needs becomes apparent. What does not become 
apparent is the level of power system technology necessary to meet the real needs of military and civilian applications. The schedules and budgets required to develop power systems which are time-compatible with missions must be factored into a plan for development - a technology roadmap. The roadmap for power systems must begin with the complete nuclear power system technology base that exists in the United States today.

\section{Background}

The U.S. development of a steady-state space nuclear reactor power system technology base began in the early 1950s. Reactor systems were code-named with even-numbered "SNAP" designators and were initially considered with power capabilities from hundreds of watts through multi-kilowatts. The principal SNAP reactor power systems were SNAP-2, SNAP-8, SNAP-10A, SNAP-50, and the SNAP follow-on concepts (Figure 8). All the numerically designated systems were designed for a l-year power duration, with power capabilities ranging from $0.5 \mathrm{kWe}$ to $350 \mathrm{kWe}$. The follow-on system concepts were aimed at 2- to 7-year lives with power capabilities up to $75 \mathrm{kWe}$. The SNAP-2, -8, -10A, and follow-on systems were based on a thermal reactor using uranium zirconium hydride fuel. The SNAP-50 was based on a fast reactor using uranium nitride fuet. 
The hardware phase of the SNAP program occurred in the 1960s and centered around the SNAP-2, $-8,-10 A$, and -50 systems. Separate reactor and power conversion subsystem development/test was performed for the SNAP-2 and -8 systems. The SNAP-IOA system included reactor development, power conversion subsystems development, and full-up system testing on the ground and in space. The SNAP-50 program included component development testing, and did not proceed through reactor or system fabrication and testing. The SNAP follow-on concepts were oriented at subsystem technology improvement, and drew their data base largely from the SNAP-2, -8, and $-10 A$ programs. The major hardware milestones in the SNAP program included the SNAP-10A ground test and flight tests in 1965 and the SNAP-8 reactor demonstration tests in the 1960s (Figure 9).

Paralleling this hardware phase was the Aerospace Nuclear Safety Program (Figure 9). Approximately $\$ 50$ million (1960s dollars) was spent in this program alone to verify the safety of nuclear reactor systems before launch, during launch, in space, and upon reentry.

Early in the 1970s, system concepting and subsystem improvement activities were underway. These activities included the design of various reactor power systems such as the 5-kWe Reactor Thermoelectric System and the 75-kWe Reactor Turboelectric System (Figure 9). At the end of this improvement phase, the uranium zirconium hydride reactor system technology base was well on its way to providing a 25-kWe system with a 5-year life. Over the range of 
powers being considered at that time, specific powers of 6 to $30 \mathrm{~W} / \mathrm{kg}$ were projected. These systems had Tonger lifetimes and specific energy capabilities of 30 to $210 \mathrm{~W}-\mathrm{yr} / \mathrm{kg}$. The uranium nitride reactor system technology base was oriented to much higher powers, with SNAP-50 type systems offering large increases in specific power and energy.

The SNAP Program was terminated later in the 1970s. At that time, several hundred million dollars had been invested in the technology base, with over $\$ 200$ million of this investment at Atomics International.

System, Subsystem, and Component Implications

The technology base which was most completely demonstrated and supported by test resulted from the SNAP-10A and SNAP-8 programs. This base was also used in the SNAP follow-on programs. Another technology base was established by the higher power, higher temperature SNAP-50 program.

The SNAP-10A, -8, and follow-on programs considered various types of power conversion, but the reactor and shielding concepts were similar for all systems. The reactors were therma 1 , based on uranium zirconium hydride fue 1. The hydrogen moderator was intrinsically bound in the fuel matrix. This was done to minimize fuel inventory and maximize reactor safety. Fuel composition for all reactors was generally the same, using $10 \mathrm{w} / 0$ (weight percent) fully 
enriched uranium and $90 \mathrm{w} / 0$ zirconium. The fuel was hydrided to $6 \times 10^{22}$ hydrogen atoms/cc or about the same hydrogen density as water. The reactors were cooled with a liquid metal eutectic, Nak-78 (78 w/o potassium). Reactor neutron shielding used lithium hydride $(\mathrm{LiH})$ in a stainless steel containment vesse 1. Gamma shielding, when employed, used heavy metals.

The SNAP-10A system, launched on April 3, 1965, was designated Flight System 4 (Figure 10). The total spacecraft was called SNAPSHOT and included the Agena vericle with primary and secondary payloads. The SNAPSHOT spacecraft was launched into a $1,300-\mathrm{km}$ (700 nautical mile) orbit with approximately a 3,500-yr orbit life. The SNAP-10A reactor power system initially produced $580 \mathrm{~W}$ (electric) in orbit. SNAP-10A was designed to be actively controlled only at the beginning of its life; and after the reactor was stabilized, electric power drifted down with time. SNAP-10A performance in space tracked the performance of the ground test system (Flight system 3, see below). At the forty-third day of in-space operation, following Orbit 553, telenetry from the SNAPSHOT spacecraft was lost. It was later determined that thermal overstressing of the Agena voltage regulator caused an erroneous shutdown cormand to the reactor's permanent shutdown device.

The SNAP-10A system had a single NaK loop and employed silicon-germanium thermoelectric elements (Figure 11). The reactor coolant outlet temperature was $833^{\circ} \mathrm{K}\left(1040^{\circ} \mathrm{F}\right)$. The unshielded reactor mass per unit thermal energy was $2,650 \mathrm{~kg} /$ lWt-yr. The overall system had a specific power of $1.3 \mathrm{~W} / \mathrm{kg}$. Because the system was designed for a 1-year life, the specific energy was equal to the specific power. 
SNAP-10A Flight System 3 was tested on the ground in vacuum for 10,000 hours at power and temperature (Figure 12). The ground test was initiated prior to Flight System 4 launch, so that flight performance could be tracked against ground performance. The ground test system operated at the same reactor outlet temperature and average radiator temperature as the flight test system. The effective higher sink temperature of the ground facility versus space resulted in lower power output from the ground test system.

Because of the concerns of launching a reactor system into space, a significant safety program supported the SNAPSHOT Iaunch (Figure 13). This program was called the Aerospace Nuclear Safety Program and supported reactor and radioisotope system development activities. Both safety analysis and testing were performed for the SNAPSHOT launch. In the Reentry Flight Demonstration Test, a full-scale nonfueled and nonradioactive replica of the SNAP-1OA reactor was launched and subjected to a suborbital flight path. This test demonstrated beryllium reflector separation from the reactor vessel and also supported theoretical modeling in areas such as aerodynamic heating and reactor disassembly.

A highlight of the safety program was a series of reactor transient tests called the SNAPTRAN experiments. These experiments were used to measure the response to rapid reactivity insertions and core water flooding. SNAPTRAN-3 was specifically conducted to characterize the SNAP-10A reactor in 
the water-flooding event which could follow a launch abort (Figure 14). In this experiment, a SNAP-10A core was located in a water-filled environmental chamber. The core was surrounded by a poisoned and voided sleeve. The sleeve was pyrotechnically removed and the reactor was destructed. The expansion of the well-instrumented core was followed by three high-speed cameras, and the data collected was used to determine coefficients of reactivity versus volume expansion. Experimental data also verified that the reactivity temperature coefficient was $-0.4 \notin /{ }^{\circ} \mathrm{C}$ prior to the initiation of core expansion. The SNAPTRAN-3 experiment further demonstrated that fuel element disintegration was caused by the generation of hydrogen overpressure. The one intact fuel element from the experiment showed that this hydrogen evolution was nonuniform about the cross section of the fuel (Figure 14). A very positive outcome of the experiment was confirmation that a high fraction of the fission products were retained in the fuel element.

The SNAP-8 program was directed at a 600-kWt reactor with a $978^{\circ} \mathrm{K}$ $\left(1300^{\circ} \mathrm{F}\right)$ coolant outlet temperature. The reactor was to be used with higher electric power mercury Rankine turboelectric power conversion subsystems. Two complete reactors were tested in this program - the SNAP-8 Experimental Reactor (S8ER) and the SNAP-8 Developmental Reactor (S8DR).

The S8ER was tested in an inerted containment vessel for 12,000 hours and operated for 1 year at power and temperature (Figure 15). The reactor employed nonflight-type hardware and the test did not incorporate flight-type 
neutron or gamma shields. The technology of the S\&ER was over a factor of 6 iriproved from SNAP-10A, i.e., for a given unshielded reactor mass, S8ER could deliver over six times the energy $(420 \mathrm{~kg} / \mathrm{MWt}-\mathrm{yr})$.

The SNAP-8 Developmental Reactor was ground tested for 7,000 hours at powers from 600 to $1,000 \mathrm{kWt}$ (Figure 16). Testing was performed in vacuum using flight-type reactor components and a flight-type neutron shield. The actuators were bidirectional, and the reflectors incorporated a separate ground test scram mechanism. The S8DR had an unshielded reactor mass per unit energy of $450 \mathrm{~kg} /$ MWt-yr, a value slightly higher than the value for the S8ER.

In each SNAP-8 reactor post-test examination, fuel cladding cracks were founci. Destructive examination, experimentation, and theoretical analysis confirmed that the cracks resulted from excessive fuel swelling. The fuel swelling phenomena was characterized, and this resulted in a temperature limit of $922^{\circ} \mathrm{K}\left(1200^{\circ} \mathrm{F}\right)$ being established for the outlet temperatures of follow-on uranium zirconium hydride reactor designs.

The SNAP-8 reactors were designed and tested for use with mercury Rankine turboelectric power conversion subsystems. The total SNAP-8 system was intended to generate 30 to $60 \mathrm{kWe}$ (nominal $50 \mathrm{kWe}$ ) at reactor powers of 300 to $600 \mathrm{kWt}$. The mercury Rankine power conversion subsystem was being developed by Aeroject Corporation under direction of the NASA Lewis Research Center. NASA-LERC was also investigating the gas Brayton power conversion subsystem for this application. Based on development test results for the mercury 
Rankine unit, the SNAP-8 system efficiency was projected to be $10 \% 124 \%$ of Carnot efficiency). The total system specific power was projected in the 7 to $10 \mathrm{~W} / \mathrm{kg}$ range.

The SNAP-8 technology base was then used in the design of several SNAP follow-on reactor system concepts (Figure 17). The reactor designs were based on SNAP-8 data and ranged in power from 100 to $600 \mathrm{kWt}$. The unshielded mass per unit energy of the reactors remained in the range of 400 to $450 \mathrm{~kg} / \mathrm{MWt}-\mathrm{yr}$. The reactors and power systems were designed for longer lives, in the 2- to 7-year range. The systems incorporated various thermoelectric and turboelectric (Brayton and Rankine) power conversion subsystems. Total system specific powers were projected at 6 to $30 \mathrm{~W} / \mathrm{kg}$, depending on the absolute power level. Total system specific energies were projected at 30 to $210 \mathrm{~W}-\mathrm{yr} / \mathrm{kg}$.

The time frame during which the SNAP follow-on systems were being conceived was also the time frame for subsystem technology improvement activities. These activities were performed during the early 1970s and resulted in some expansion of the SNAP data base. This data base is discussed below for the reactor, shielding, primary heat transport, and power conversion and processing subsystems. 
The data base for the uranium zirconium hydride reactor subsystem is based on over 41,000 total hours of reactor testing (Figure 18). During this testing, peak fuel linear power densities of $11.3 \mathrm{kWt} / \mathrm{m}$ were obtained, as were peak cladding temperatures of $1015^{\circ} \mathrm{K}\left(1370^{\circ} \mathrm{F}\right)$. As mentioned earlier, the testing resulted in an imposed limit of $922^{\circ} \mathrm{K}\left(1200^{\circ} \mathrm{F}\right)$ on the $\mathrm{U}-\mathrm{ZrH}$ reactor coolant outlet temperature, with a limit of $3.3 \mathrm{kWt} / \mathrm{m}$ on average linear power density. Reflectors, reflector materials, vessel materials, coolant headers, vessel structure, high-temperature bearings, and high-temperature control actuators were also demonstrated and are part of the reactor subsystem data base. Of considerable importance is the status of control actuators. Sixty-seven actuators were tested for a total 264,000 hours. A single actuator was tested for 26,000 hours at a temperature of $880^{\circ} \mathrm{K}\left(1125^{\circ} \mathrm{F}\right)$. Other actuators were tested in reactor environments at temperatures of $644^{\circ} \mathrm{K}$ $\left(700^{\circ} \mathrm{F}\right)$. An important implication of this actuator testing is the temperature and fast-neutron dosage capabilities of these units. Higher temperatures and dosages will require new materials and insulators, with resultant actuator development and qualification.

The shielding subsystem data base results from 13 neutron shields being tested for 19,000 hours (Figure 19). In all cases, the neutron shielding material was lithium hydride. This is the consensus material for neutron shielding because it has an extremely high macroscopic neutron removal cross section per unit density $\left(0.15 \mathrm{~cm}^{2} / \mathrm{gm}\right)$. The equivalent value for water is only $0.10 \mathrm{~cm}^{2} / \mathrm{gm}$. Lithium hydride is a fabricable material, and Atomics 
International cast shields up to a diameter of $1.8 \mathrm{~m}(6 \mathrm{ft})$. The major limitation on lithium hydride as a shielding material is its operating temperature. LiH melts at $959^{\circ} \mathrm{K}\left(1266^{\circ} \mathrm{F}\right)$, and although molten lithium hydride could be used at temperatures slightly above the melting point, it is apparent that very high-temperature reactor systems will require active shield c00ling or other shielding materials. Either solution will require development.

The primary heat transport subsystem data base encompasses piping, liquid metal, electromagnetic pump, and coolant volume compensator technologies (Figure 20). In the SNAP program, 58 electromagnetic pumps were tested for 212,000 total hours, with a single pump operating successfully for 42,000 hours. These pumps operated at temperatures up to $920^{\circ} \mathrm{K}\left(1200^{\circ} \mathrm{F}\right)$. Volume compensators were also successfully demonstrated in the SNAP program. These components used metallic bellows to accommodate the differential volume expansion between the liquid metal coolant and the piping. The volume compensators also provided pressurization for the liquid metal coolant, while maintaining it void free. Fifty volume compensators were tested at elevated temperatures for over 100,000 total hours. The SNAP-10A ground system compensator accumulated 10,000 test hours.

The power conversion and processing subsystem data base includes technologies for thermoelectric and turboelectric power conversion (Figure 21). Although the SNAP-IOA system used silicon-germanium thermoelectrics, developmental efforts were also focused on lead-telluride (PbTe) because of its 
higher potential figure of merit, $Z$ (equals material Seebeck coefficient squared divided by electrical resistivity and thermal conductivity). Leadtelluride compact tubular thermoelectric converters were designed by Westinghouse Astronuclear Laboratory and tested by both Westinghouse and Atomics Internationa 1. Two hundred and twenty units were tested for 720,000 hours, with a single unit operating for 42,000 hours. A figure of merit of $0.8 \times$ $10^{-3} \mathrm{~K}^{-1}$ was demonstrated for these converters, i.e., an efficiency of $5 \%$ at a hot clad temperature of $858^{\circ} \mathrm{K}\left(1085^{\circ} \mathrm{F}\right)$ and a cold clad temperature of $537^{\circ} \mathrm{K}\left(507^{\circ} \mathrm{F}\right)$, the required system temperatures. The turboelectric subsystems included the mercury Rankine units for SNAP-2 and SNAP-8 which were developed by TRW and Aerojet, respectively. A mercury Rankine subsystem was tested in a ful1-up SNAP-2 reactor power system configuration using an electrically simulated reactor. Thirty thousand hours of test experience were demonstrated on the mercury Rankine units with a 5,000-hour single-duration test.

In reviewing the reactor power system technology data base which evolved from the SNAP program, a question that may be asked is "What does it mean today?" Over the past 10 years, no further activities were performed on these compact reactor systems. However, in support of the Radioisotope Thermoelectric Generator (RTG) programs, development activities did proceed with silicon germanium thermoelectric power conversion. 
An interesting perspective can be gained by "concepting" a SNAP-type reactor power system using a SNAP-evolved U-ZrH reactor with current silicon germanium thermoelectric capabilities (Figure 22). To be consistent with currently envisioned mission requirements, a power system life of 7 years is used. As the design electrical power level of this system concept is increased, the specific power and specific energy capabilities of the system increase dramatically. Although SNAP-10A exhibited a specific power and energy of only $1.3 \mathrm{~W} / \mathrm{kg}$, a SNAP-evolved derivative system with a 100-kWe capability exhibits a specific power of $11 \mathrm{~W} / \mathrm{kg}$ and specific energy of $80 \mathrm{~W}-\mathrm{yr} / \mathrm{kg}$. Such large improvements are due to the economy of size, to increased reactor coolant temperature (from $833^{\circ} \mathrm{K}$ to $922^{\circ} \mathrm{K}$ ), and to improved thermoelectric converter efficiency. This system concept would still be very large and heavy in high-power ranges. The important conclusion is the dramatic system-level effect of power on the mass of such a system.

A further perspective into this effect can be gained by looking at the sarie type of SNAP-evolved power system concept, but one utilizing improved thermoelectrics (Figure 23). These improved thermoelectrics have a figure of merit of $1.0 \times 10^{-3} \mathrm{~K}^{-1}$ and have been proposed as a reasonable technology iniprovement. The specific power achievable by such a system concept at $100 \mathrm{kWe}$ is $15 \mathrm{~W} / \mathrm{kg}$. The specific energy achievable at this power is over $100 \mathrm{~W}-\mathrm{yr} / \mathrm{kg}$. 
A review and evaluation of the technology data base established by the Pratt and Whitney SNAP-50 reactor turboelectric system provides a similarly dramatic demonstration of the system-level effect of power on mass. SNAP-50 was being configured for power levels of 300 to $1000 \mathrm{kWe}$. The system employed a fast uranium nitride reactor, operating at a lithium coolant temperature of $1367^{\circ} \mathrm{K}\left(2000^{\circ} \mathrm{F}\right)$. The reactor was projected to have an unshielded mass per unit energy of $730 \mathrm{~kg} / \mathrm{MWt}-\mathrm{yr}$. The projected system conversion efficiency was $14 \%$ using a potassium Rankine turboelectric power conversion subsystem. SNAP-50 was being designed for a l-year life and was projected to have an unshielded specific power in the range of 100 to $200 \mathrm{~W} / \mathrm{kg}$.

The key conclusion from this review and evaluation of the SNAP technology data base is that an "order-of-magnitude" power system technology improvement is not required to meet the specific power and specific energy goals envisioned for future space missions. These goals are currently in the ranges of 40 to $50 \mathrm{~W} / \mathrm{kg}$ and 250 to $350 \mathrm{~W}-\mathrm{yr} / \mathrm{kg}$. Extrapolations of all types of past system technologies demonstrate that these goals seem reasonable with newer, more advanced technologies. It is only necessary to determine the level of technology advancement necessary to meet real mission needs.

Mission Considerations

Reactor power systems have always been directed at next-generation, farterm missions. In the early 1960s, reactor-powered space station concepts 
were being studied (Figure 24). As power system concepts and missions evolved, the 1970s envisioned reactor-powered lunar and space stations (Figure 25). In the 1980s, the Galileo mission to explore Jupiter is being planned (Figure 26).

Today, the most important activity for the space nuclear power community is determining if any mission requires a reactor power system. As a starting point in the search for a mission, we can turn to the Soviets and note their use of reactor power for RORSAT. Surveillance is a potential mission with a potential near-term need. A possible technology for this mission had its initial demonstration on the second shuttle voyage. This technology is synthetic aperture radar, demonstrated in the Shuttle Imaging Radar (SIR-A) experiment. SIR-A was built by the Jet Propulsion Laboratory as part of the OSTA-1 (Office of Space and Terrestrial Applications) experimental package (Figure 27). SIR-A operated at an altitude of $260 \mathrm{~km}$ (140 nautical miles). Interesting views from SIR-A include an oil slick near Venezuela (Figure 28), oil derricks near Abu Dhabi in the Persian Gulf (Figure 29), and freeways in the Los Angeles basin (Figure 30). SIR-A required a power of only $1 \mathrm{kWe}$. It does not take much imagination to envision the capabilities of a near-term radar system having 20 or 30 kWe of power.

A radar surveillance system is only one potential mission. It does, however, illustrate one truism - mission power needs will increase with time, and power system capabilities must follow these needs. As the power 
needs continue to increase, the necessity for reactor power systems will increase. Relooking at the mission "requirements" space (from Figure 7) with a time variable imposed, a possible progression of power system capabilities over time can be seen (Figure 31). This time dependence is different for steady-state and semicontinuous missions. In the late 1980s, there could be near-term missions, and only certain power system technologies may be capable of rieeting near-terri mission needs. In the early 1990s and mid-1990s, there could be mid-term and far-term missions. Mid-term and far-term reactor power systems will be available to meet mid-term and far-term mission needs only if proper planning is performed now. This planning is the technology roadmap which fits time-phased mission needs to realistically achievable power systeris.

\section{Technology-Mission Overview}

The determination of such a technology roadmap was recommended to the Department of Energy by Rockwell International. The Energy Systems Group of Rockwell International is currently performing a technology-mission overview study to determine this roadmap for the DOE. The study uses a "bottom-up" approach to assess power system capabilities, and ties these capabilities to validated rission needs generated by the Department of Defense and the NASA (Figure 32). 
An important feature of the study is a technology assessment. In the "botton-up" study approach, reactor power system technologies are first assessed at the subsystem level. Five subsystems are defined for this assessment (Figure 33). For each subsystem, current technologies are assessed, as are the future capabilities of improved technologies for mid-term needs and advanced technologies for far-term needs. Of prime importance is the consideration of development time and development cost for each improved or advanced technology. When complete, the technology assessment provides timeconpatible building blocks, i.e., subsystems whose development can be achieved in the same time frame. These building blocks are then used to generate systems whose schedular availability can be time phased by near-term, mid-term, and far-term Initial Operating Capability (IOC).

In parallel, the study implements a review of near-term, mid-term, and far-term power system capabilities with the users - the military users and the civilian users. The needs of the users are correlated with the schedular avaiTability of the power systems. Power system requirements are iterated with the users' mission needs (Figure 34). Considerations of development cost and development schedule will then result in a preferred technology roadmap for reactor power systems (Figure 35). The technology roadmap will correlate cost to schedule and need. The generation and use of this technology roadmap will assure that space nuclear power is no longer 20 years ahead of its time (Figure 36 ). 


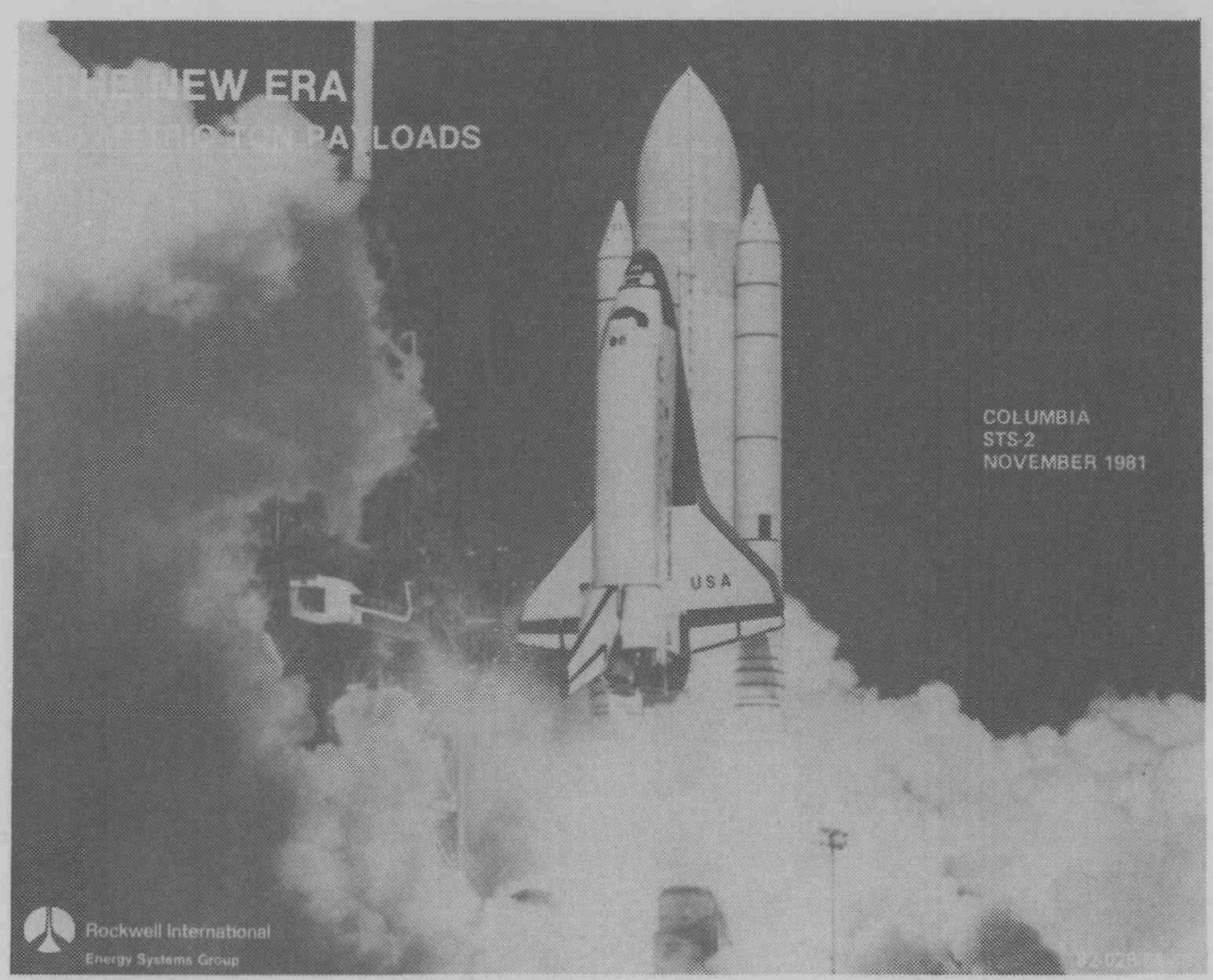

Figure 1

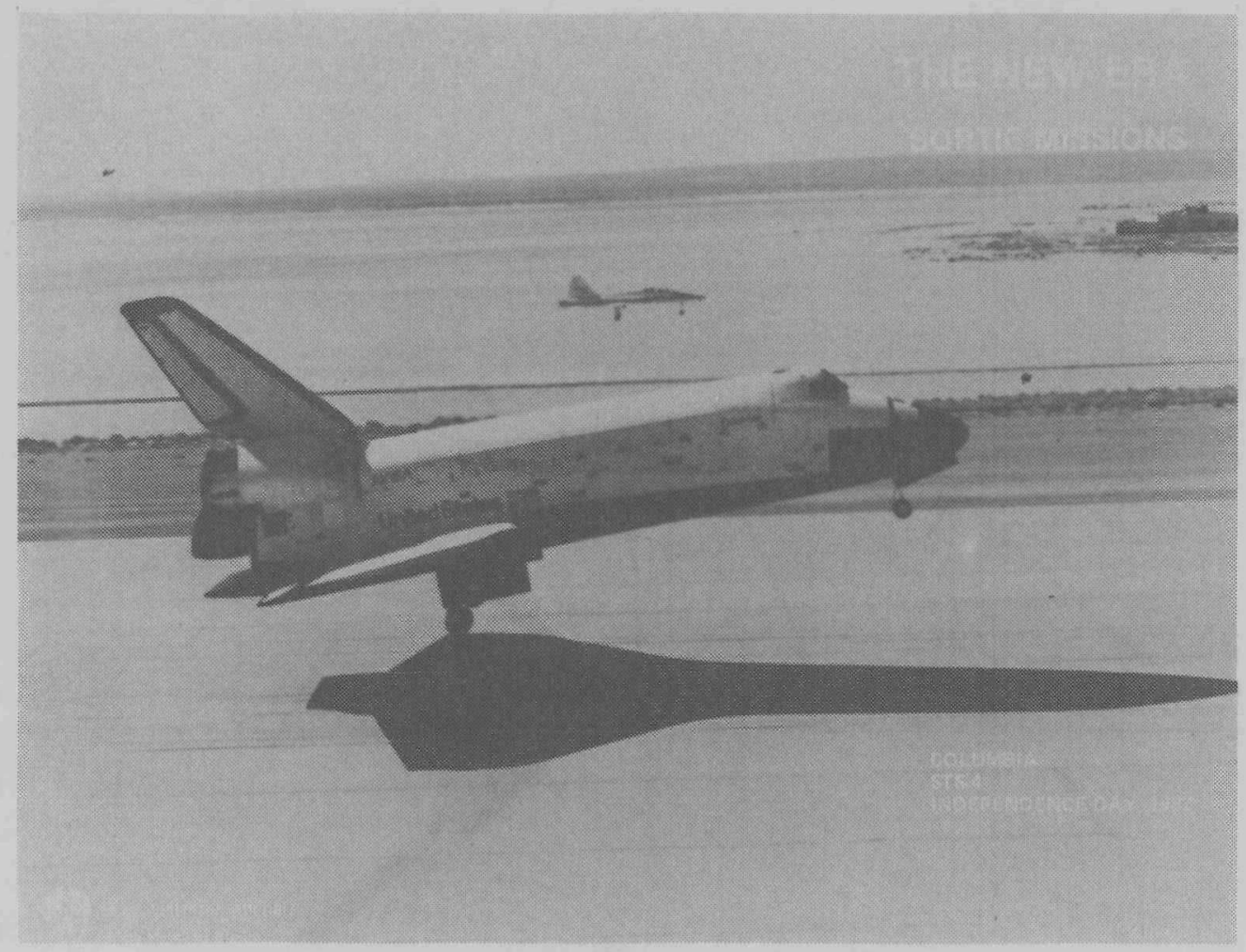

Figure 2 


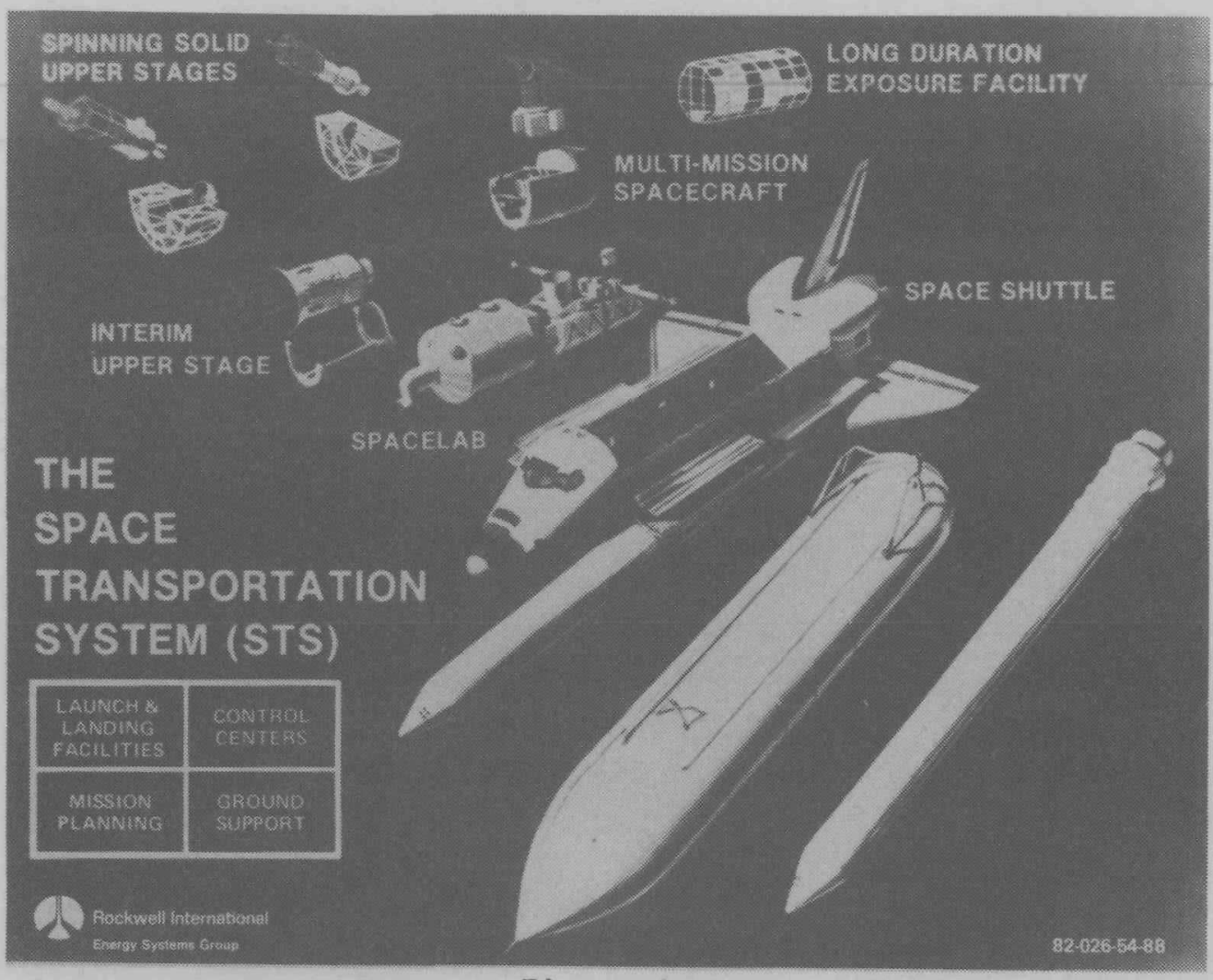

Figure 3

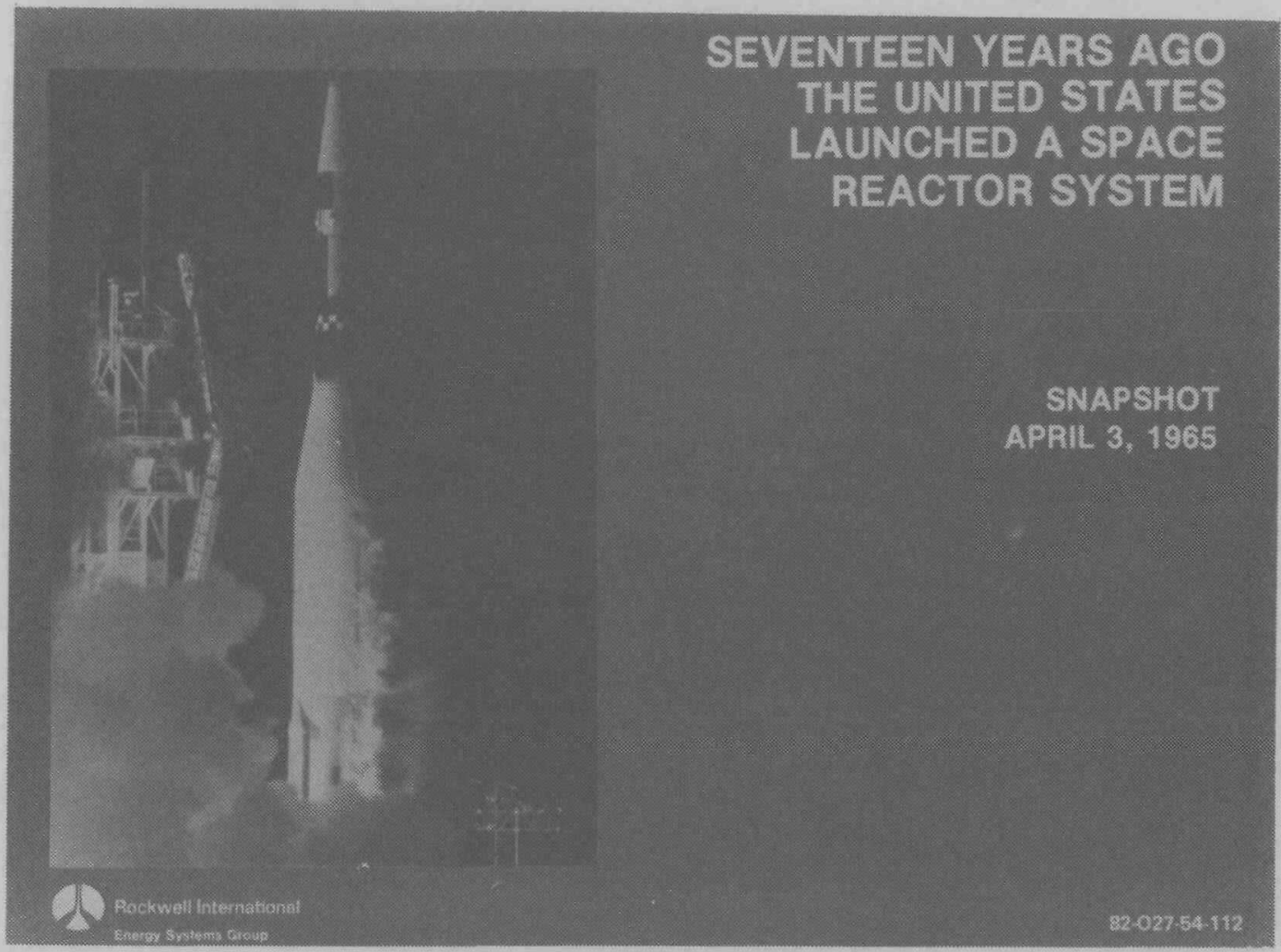

Figure 4 


\section{Rockwell International

U.S. PRINCIPAL 'COMPETITOR' COPIID AN EARIY VERSION OF THIS REACTOR SYSTEM

state REActor-

THERMOEZECTRIC

srstans
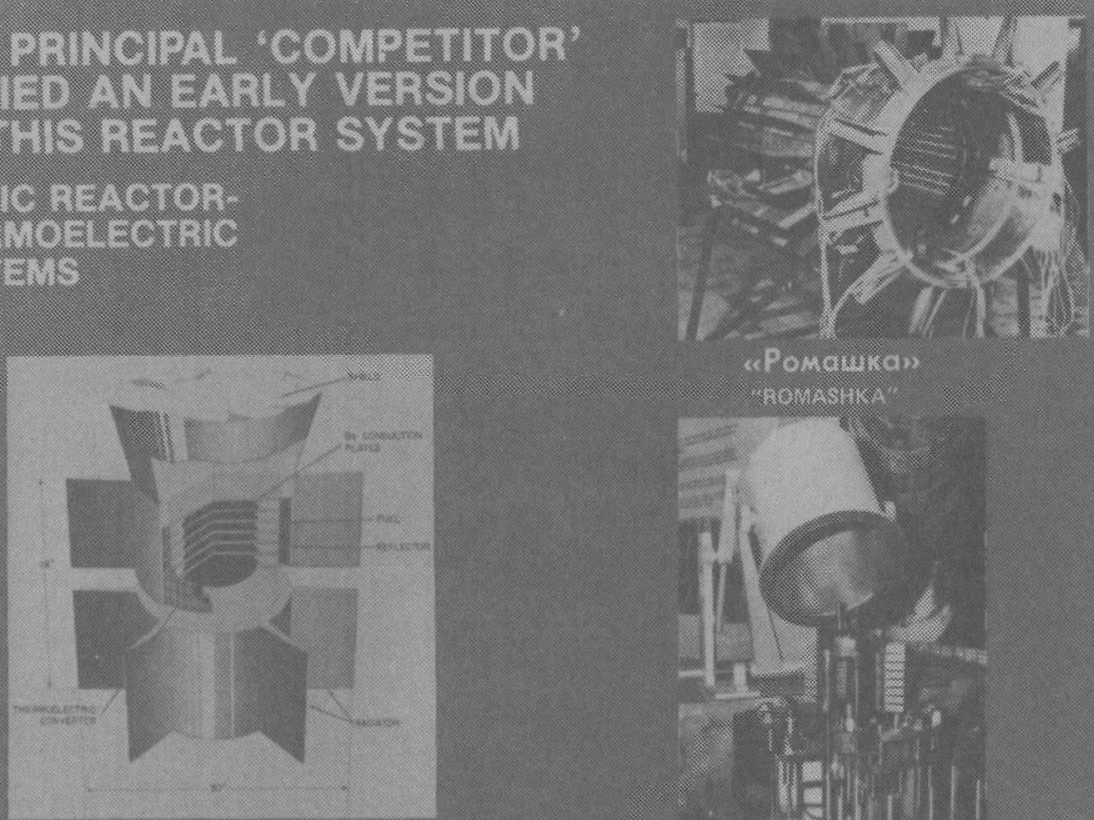

"Pomaturan

ORIGINAL SNAP-10

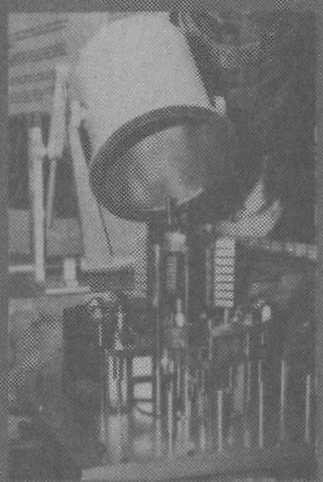

\section{Figure 5}

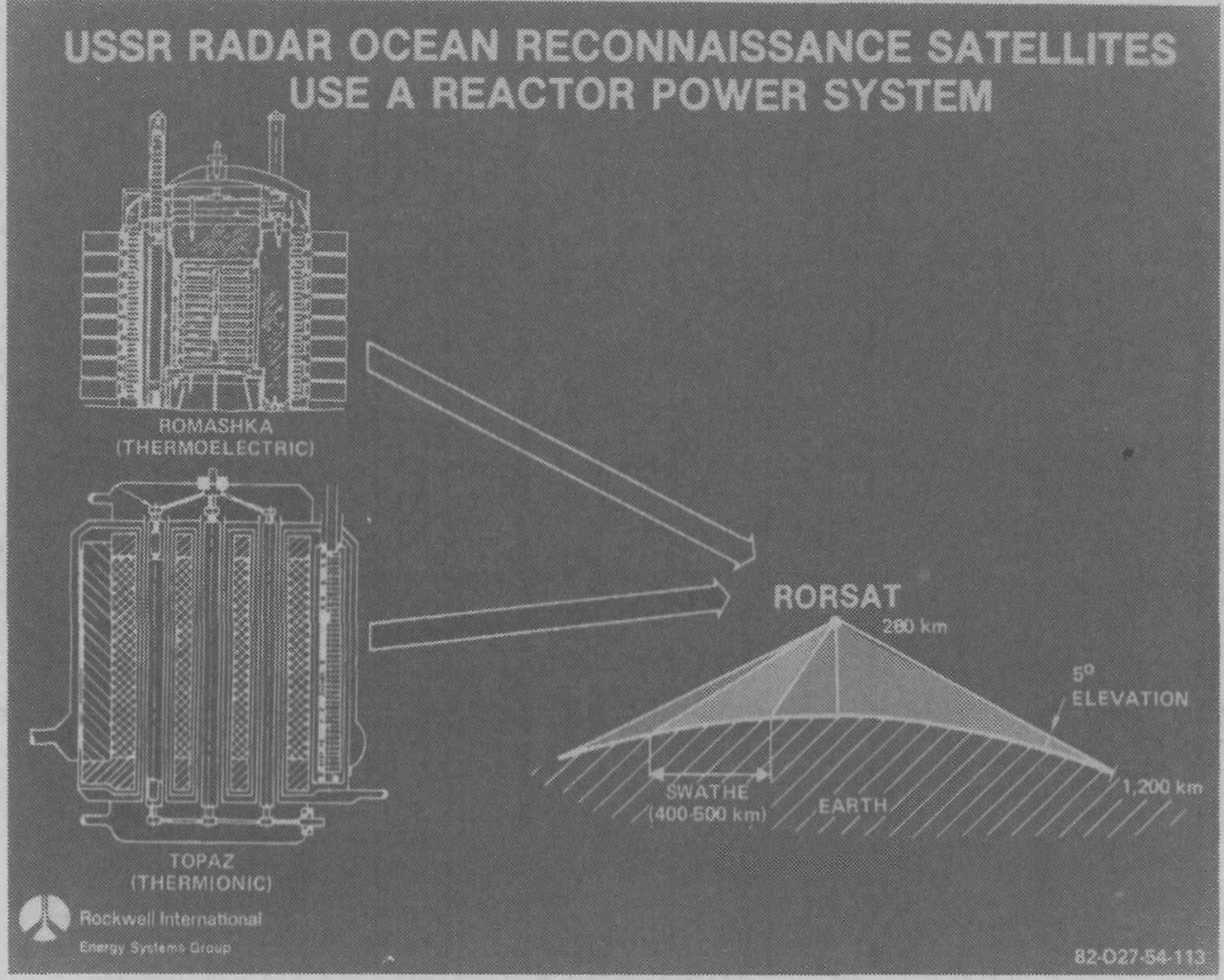

Figure 6 


\section{U.S. MISSION REQUIREMENTS SPAN BROAD RANGES} TWO MISSION TYPES ARE APPARENT

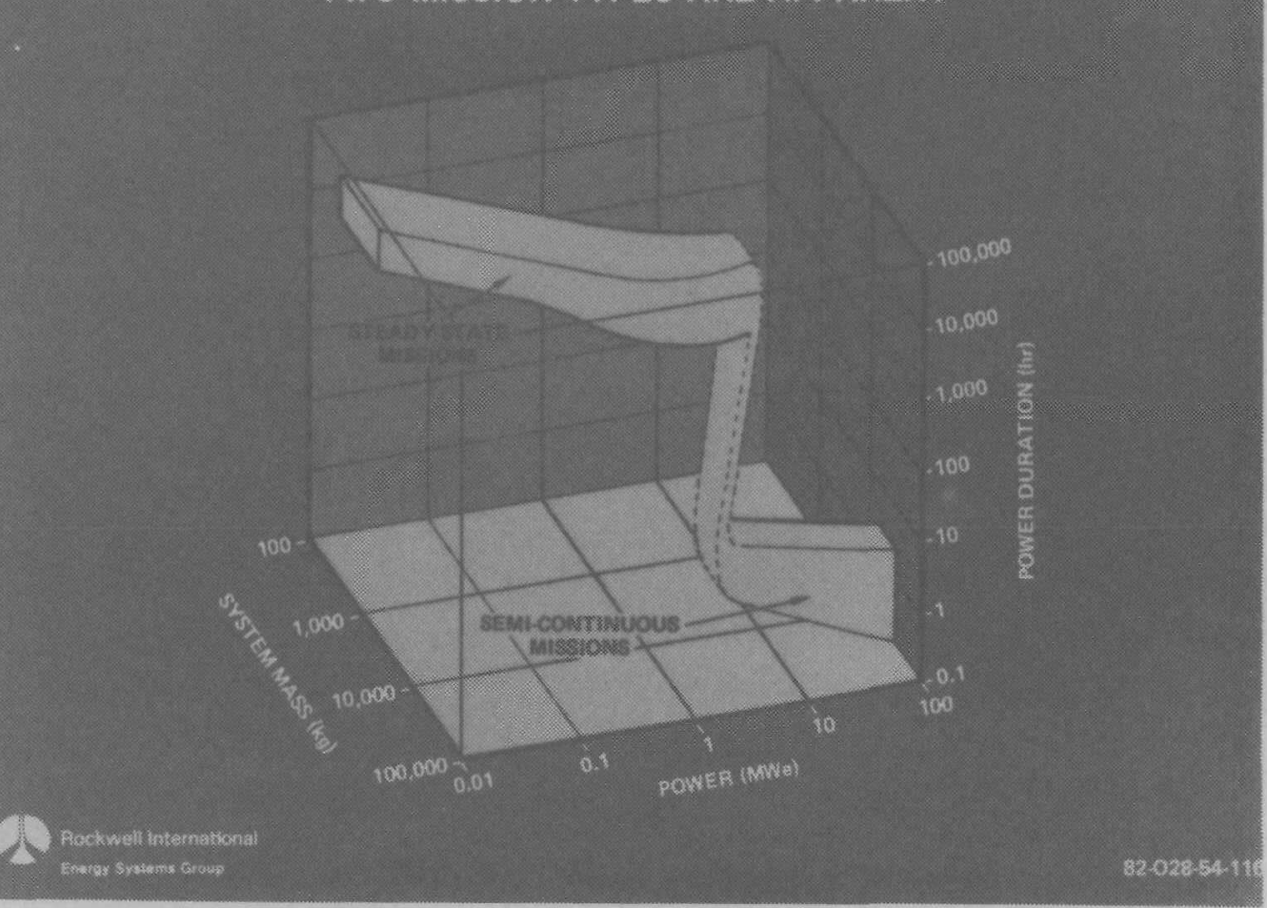

Figure 7

SYSTEMS FOR NUCLEAR AUXILIARY POWER PROGRAM REACTOR ELECTRIC SYSTEMS

\begin{tabular}{|c|c|c|c|c|c|c|c|}
\hline systens & $\begin{array}{l}\text { sxitem } \\
\text { conthaton }\end{array}$ & $\begin{array}{l}\text { Gethicai } \\
\text { Powea }\end{array}$ & 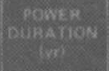 & AcActoh: & $\begin{array}{l}\text { Beqcron } \\
\text { covithacton }\end{array}$ & CONYNER & $\begin{array}{l}\text { POWEA } \\
\text { convension } \\
\text { conrracrog }\end{array}$ \\
\hline skaps & Aloomes : & 3. & $y$ & Wratix & 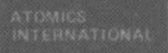 & 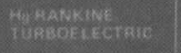 & ThW \\
\hline sNare & ateosist & 50 & 8. & Wraty & $\begin{array}{l}\text { A Rromes } \\
\text { INTERTATIONAL }\end{array}$ & $\begin{array}{l}\text { Ho RANKINE } \\
\text { TURABELECrRic }\end{array}$ & Aeroue $\mathrm{T}$ \\
\hline SPrap $10 \mathrm{~A}$ & 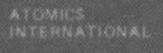 & 0.5 & i. & orithont & $\begin{array}{l}\text { Aromics } \\
\text { INIERATIONAL }\end{array}$ & Sirgen RMoel Eernic & BCA. \\
\hline saress & PRA I ANO & 350 & 4. & UN $F A S T$ & $\begin{array}{l}\text { PAAT AN AND } \\
\text { WHINEY }\end{array}$ & 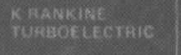 & AIRESEARCH \\
\hline $\begin{array}{l}\text { WANNED SPACE } \\
\text { STAMTON SYSTER }\end{array}$ & $\begin{array}{l}\text { AToruics } \\
\text { MNTERATINAL }\end{array}$ & 3 & 2 & UzHen: & $\begin{array}{l}\text { Áromics } \\
\text { INTERBNATIONAL }\end{array}$ & THERMOELEC CRMIC & WESTINGHOUSE \\
\hline $\begin{array}{l}\text { S RWA REACtrop } \\
\text { TE SYSTER }\end{array}$ & $\begin{array}{l}\text { ATOMLS } \\
\text { INTERNATIONAL: }\end{array}$ & 5: & 5 & 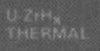 & $\begin{array}{l}\text { Aromics } \\
\text { MorefenArional }\end{array}$ & $\begin{array}{l}\text { Pbte. } \\
\text { THERMOEL FTRIC }\end{array}$ & WESTINGHGURE \\
\hline
\end{tabular}

Figure 8 


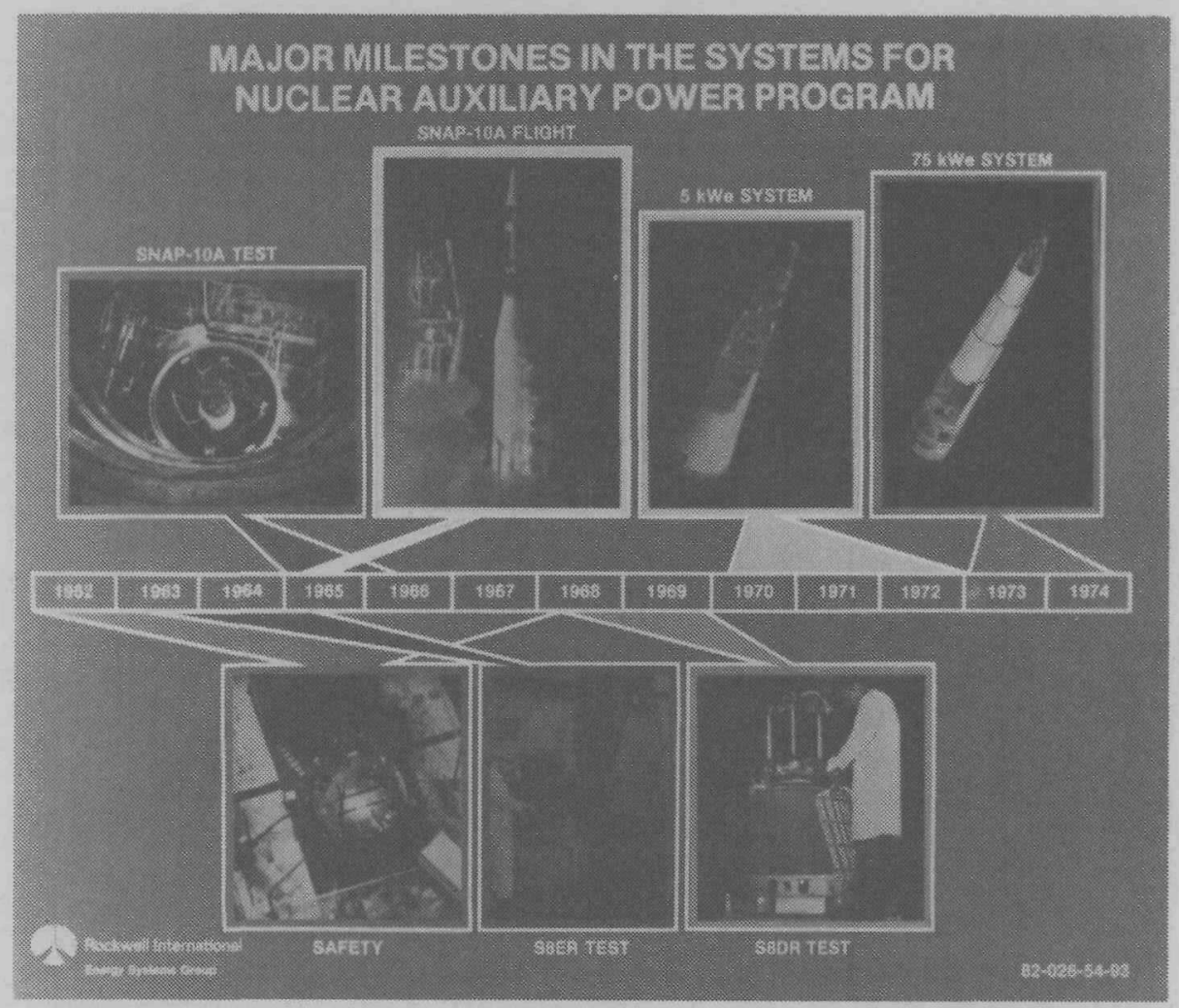

Figure 9

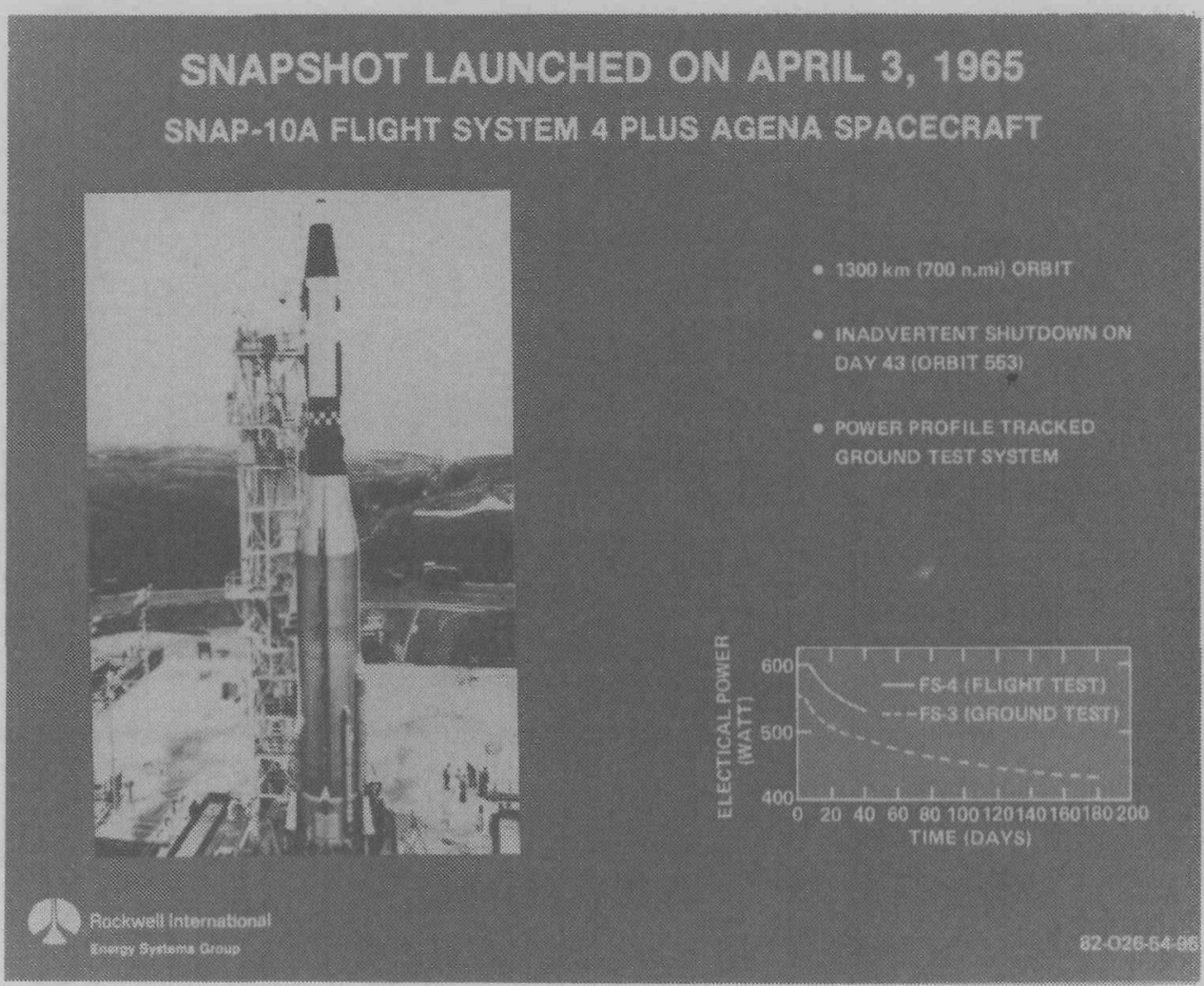

Figure 10 


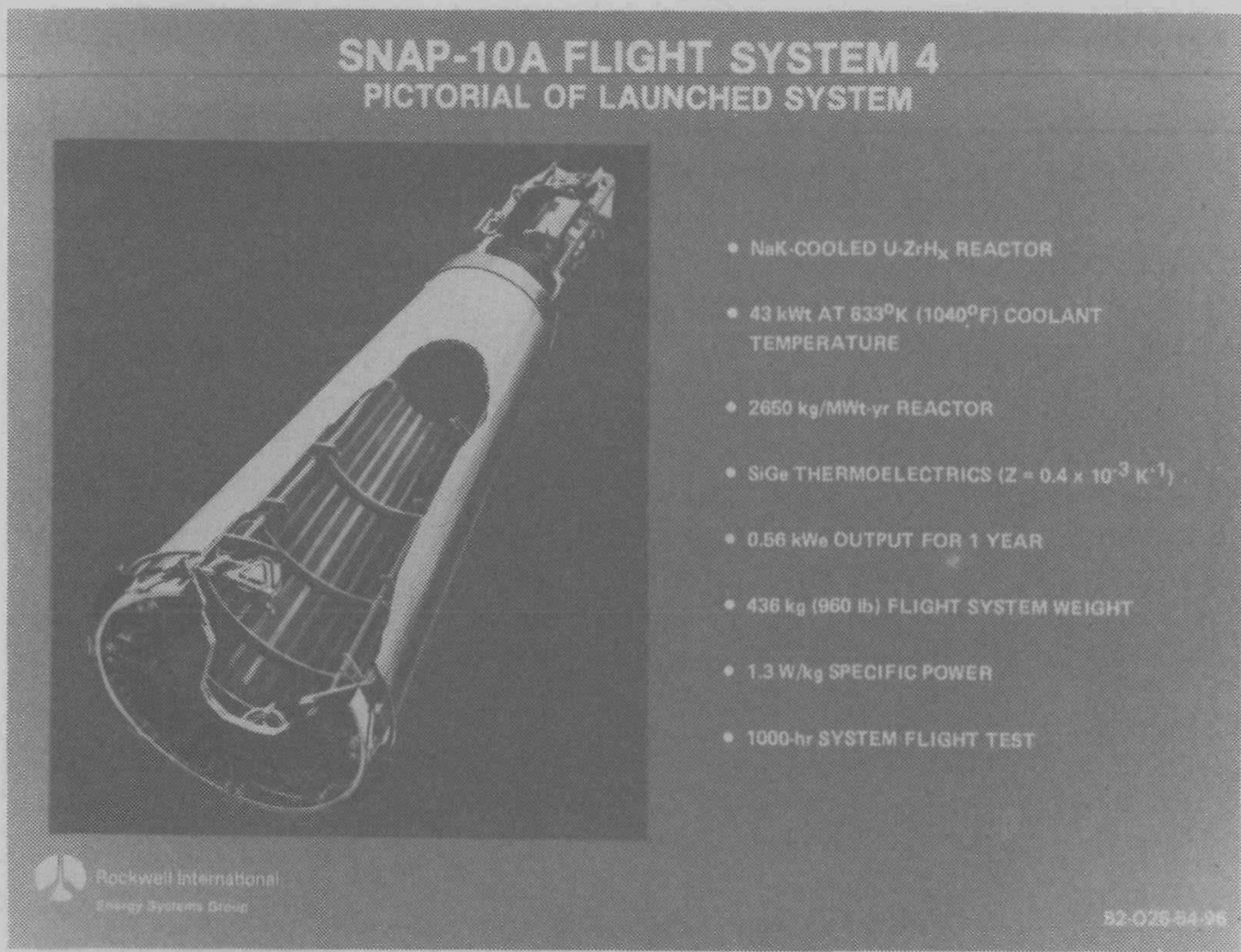

Figure 11

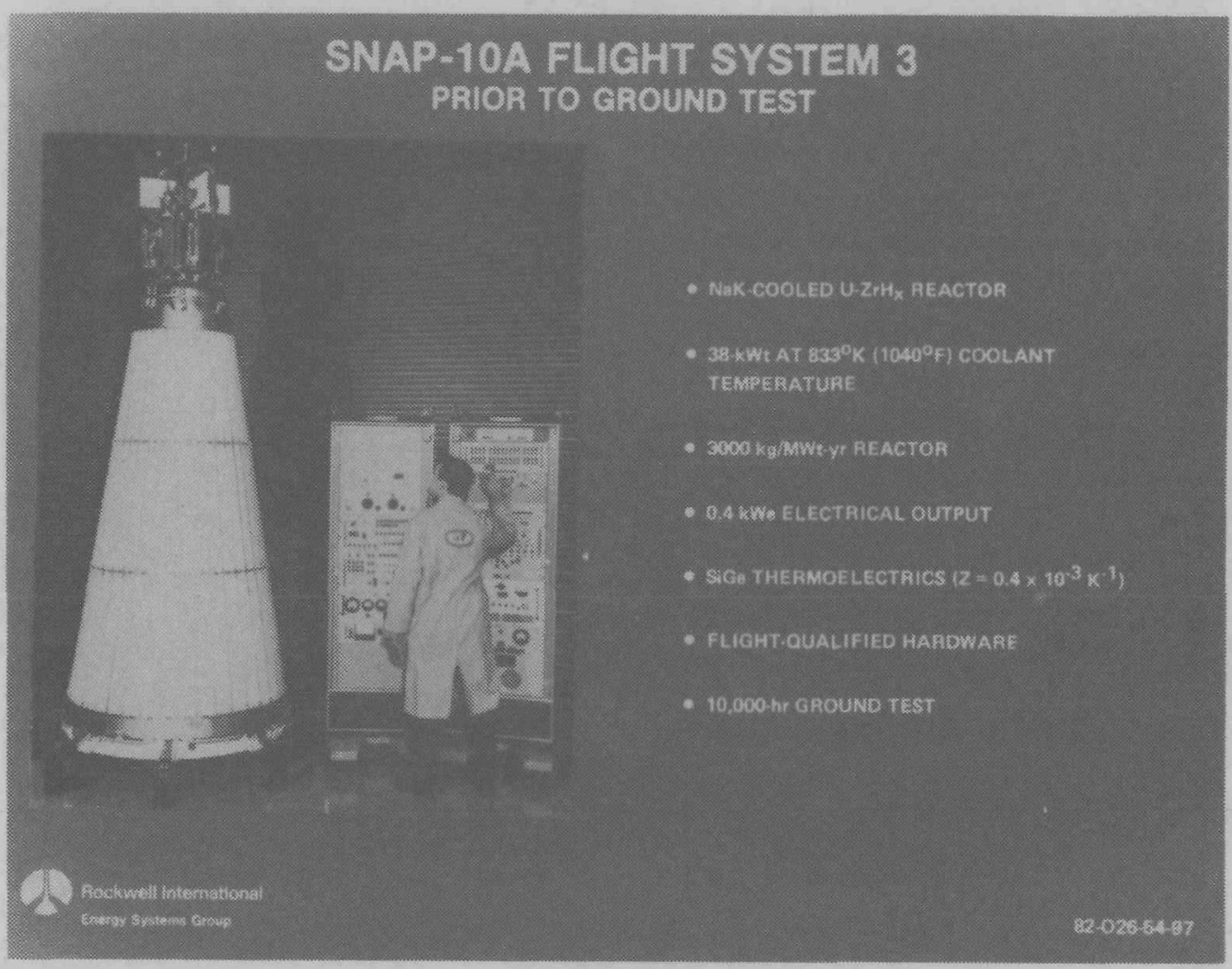

Figure 12 


\section{A SICNIFICANT SAFETY PROCRAW SUPPORTED} THE SNAPSHOT LAUNCH

MAVOR ACTVITIES PERFORMED

- ANALYSIS (REENTRY, REENTERING FUEL, PARTICLE, ...)

- REENTERING VESSEL-REFLECTOR ADHESION TESTS

- HYPERTHERMAL WIND TUNNEL TESTS (REACTOR ABLATION, FUEL BURNUP)

- FUEL PULSE HEATING EXPERIMENTS

- FISSION PRODUCT RELEASE EXPERIMENTS

- REENTRY FLIGHT DEMONSTRATION TEST (NON-RADIOACTIVE)

- SNAPTRAN-1 PROMPT NEUTRON KINETICS EXPERIMENTS

- SNAPTRAN-2 SUPERCRITICAL REACTOR DESTRUCTIVE EXCURSION

- SNAPTRAN-3 FLOODED REACTOR DESTRUCTIVE EXCURSION

- REACTOR OVERPRESSURE TESTS

- REACTOR LOX SPRAY TESTS

- REACTOR DROP AND WATER IMPACT TESTS

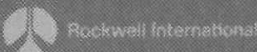

Figure 13

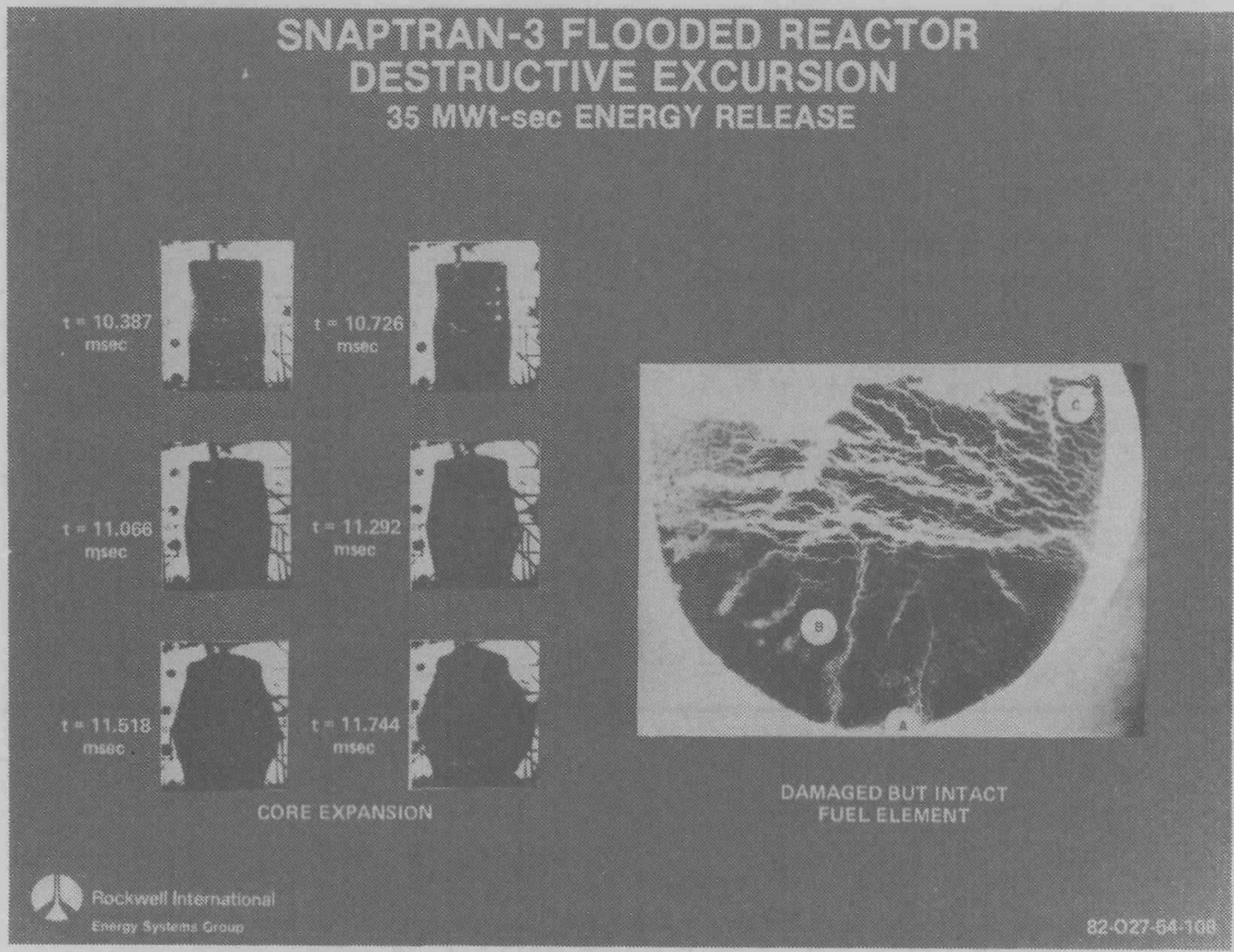

Figure 14 
1. Rockwell International

Energy Systems Group

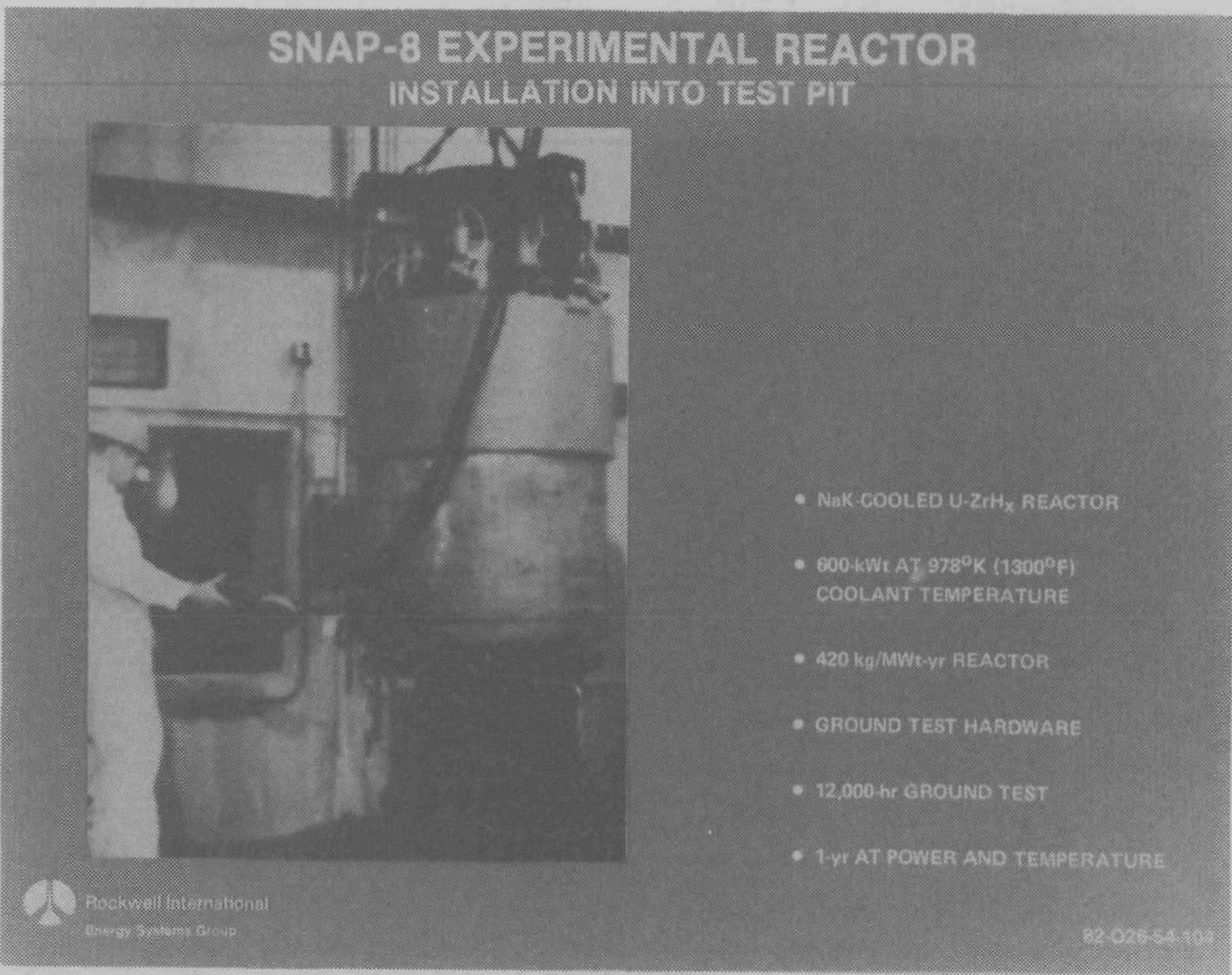

Figure 15

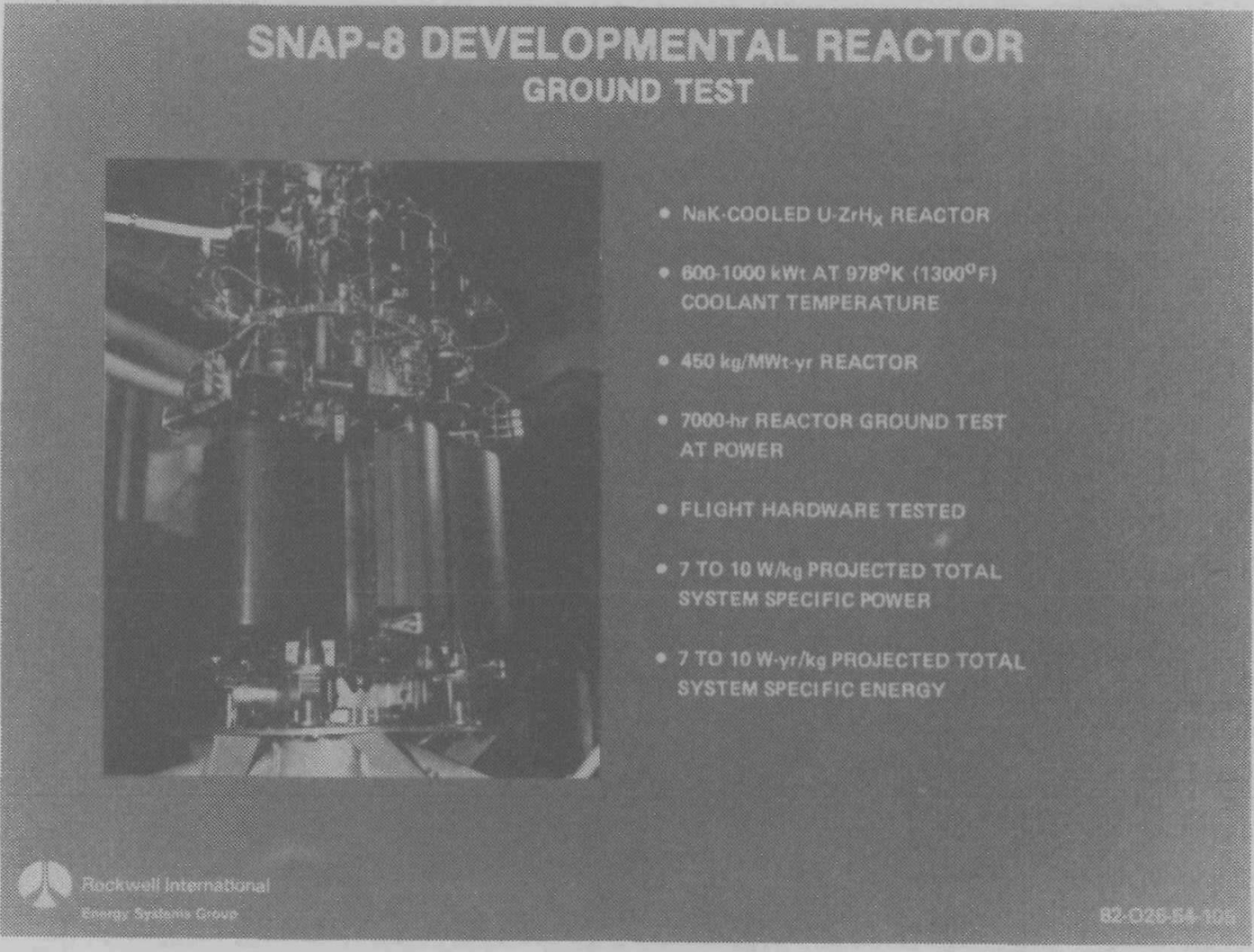

Figure 16 


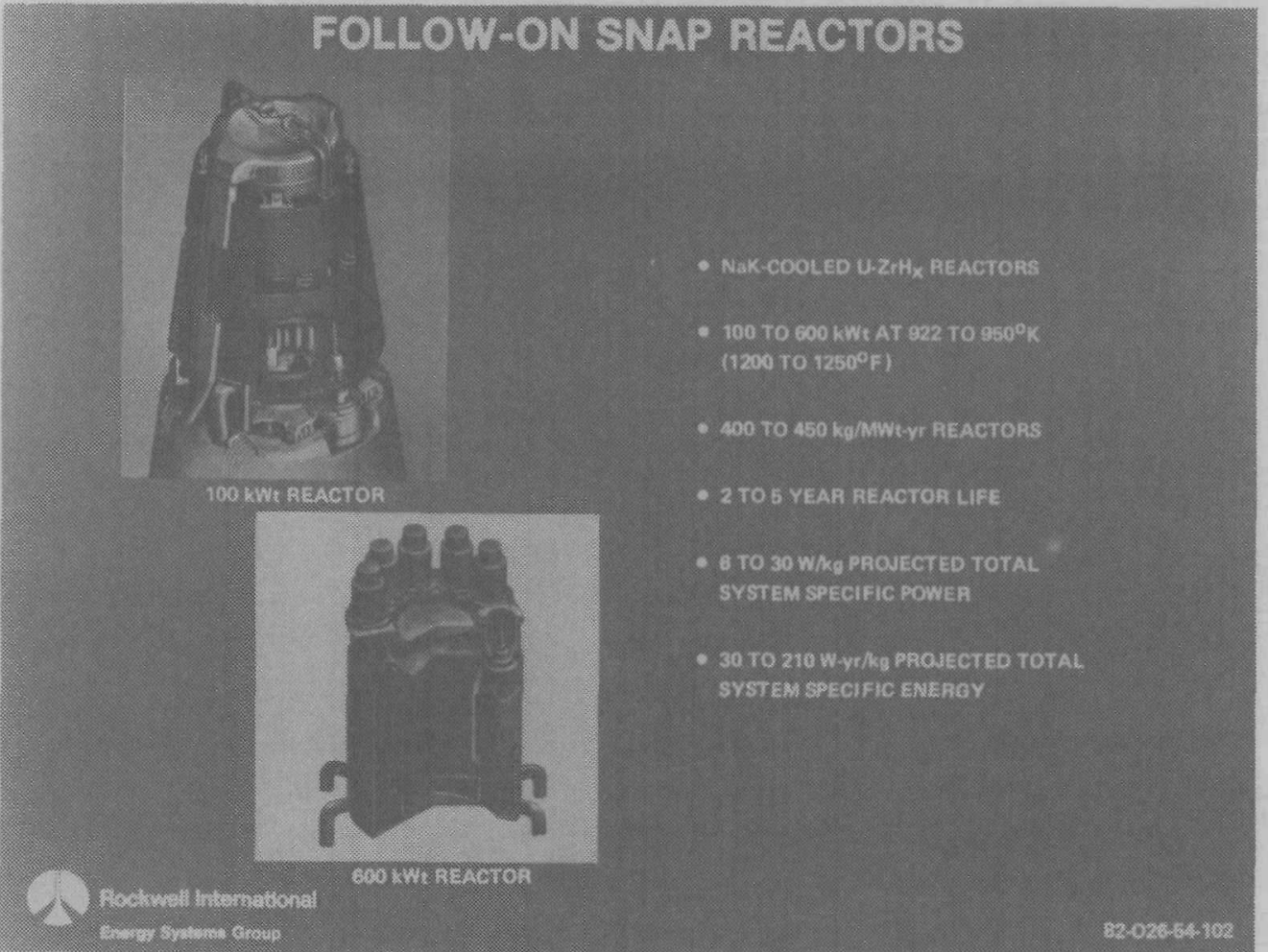

Figure 17

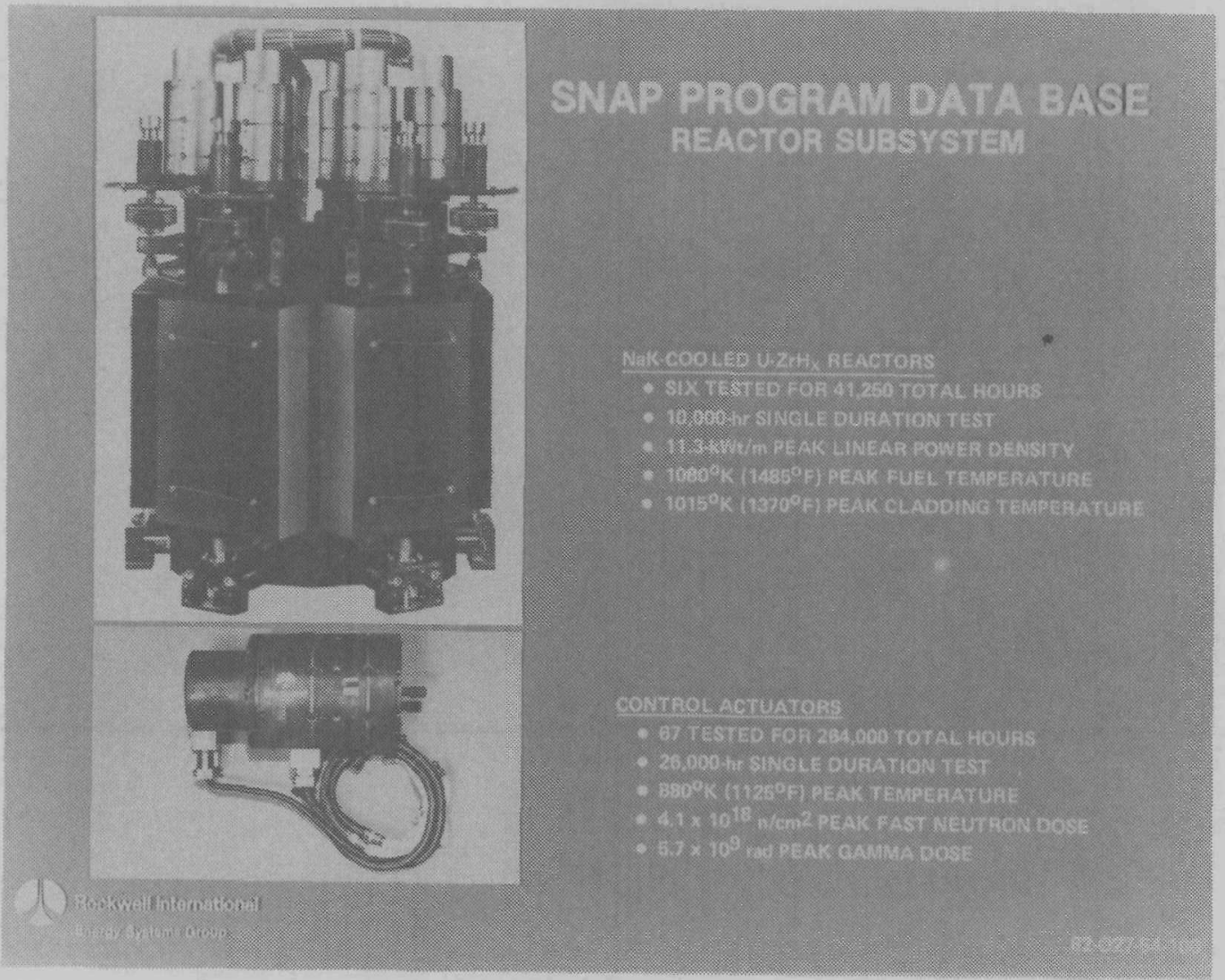

Figure 18 


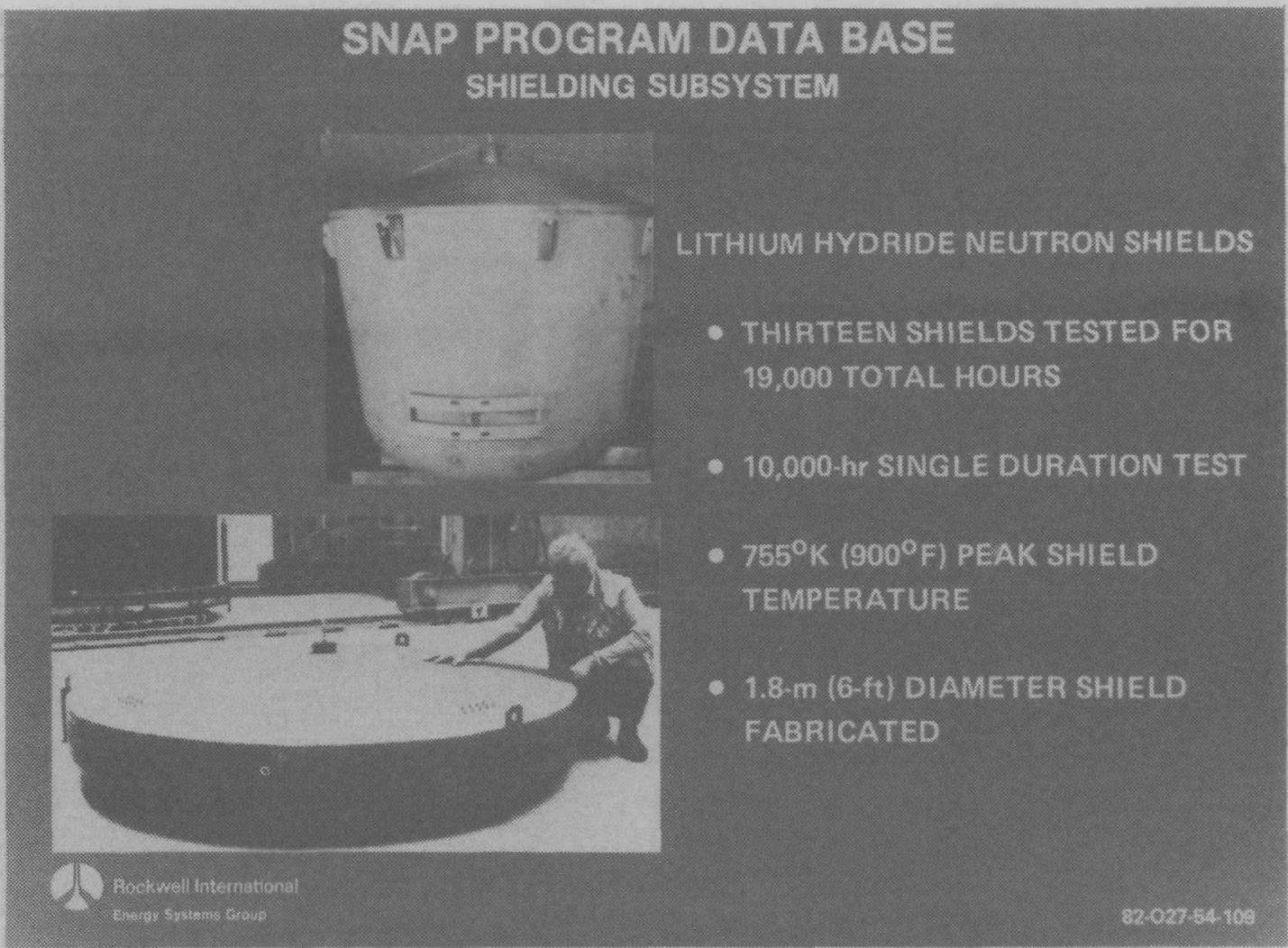

Figure 19

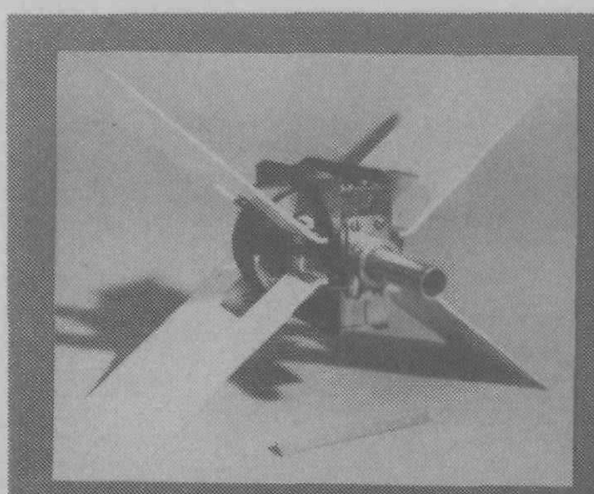

\section{SWAP PROCRAM DATA BASE}

PRIMARY HEAT TRANSPORT SUBSYSTEM

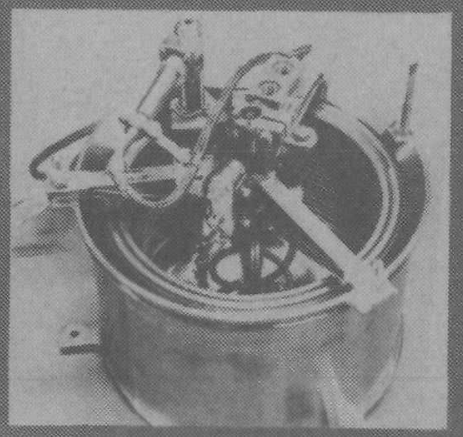

ELECTROMACNETIC LIOUID METAL PUMPS

- 58 TESTED FOR 212,000 TOTAL HOURS

- 42, aOn hI SINGLE DURATION TEST

- $920^{\circ} \mathrm{K}\left(1200^{\circ} \mathrm{F}\right)$ PEAK TEMPERATURE

- $7.6 \mathrm{~kg} / \mathrm{sec}(60.080 \mathrm{lb} / \mathrm{hr})$ PEAK NaK FL.OW

VOLUME COMPENSATORS

- 50 TESTED FOR 103,000 TOTAL HOURS

- 10,000-hir SINGLE OUAATHON TEST

- 670 $6050^{\circ}$ TI PEAK TEMPERATURE

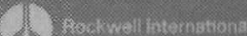

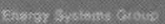

Figure 20 


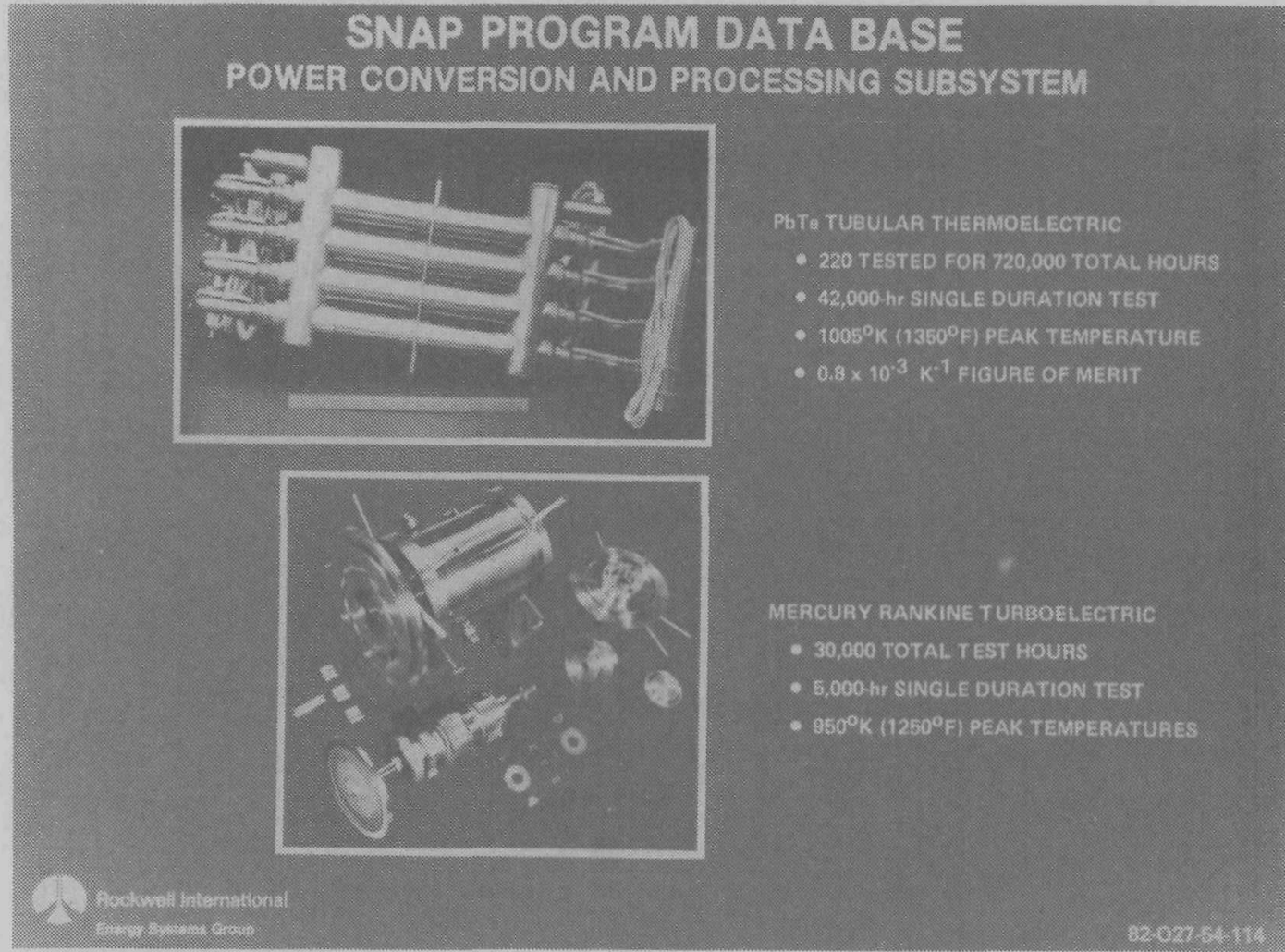

Figure 21

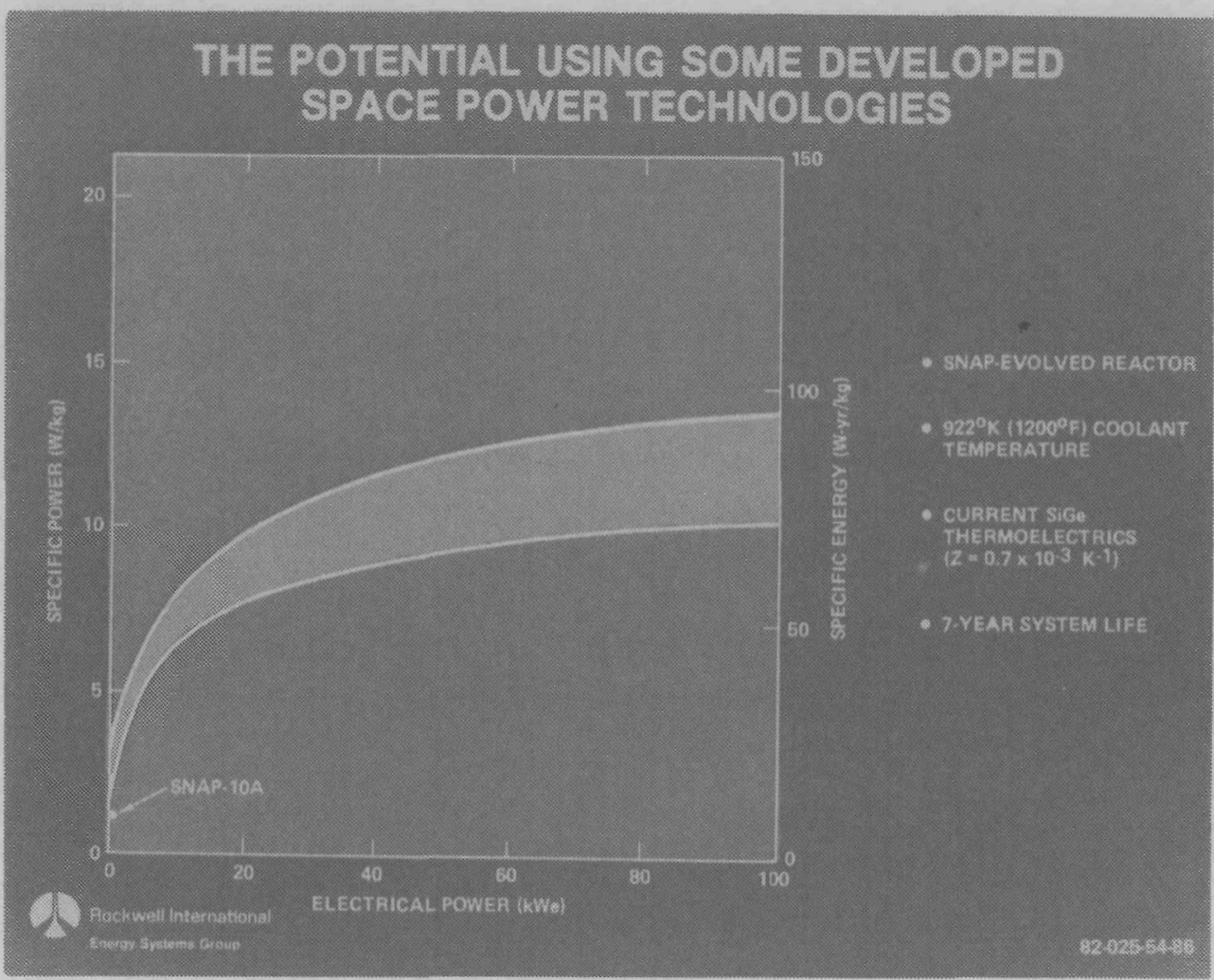

Figure 22 


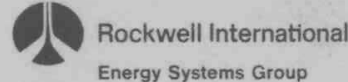

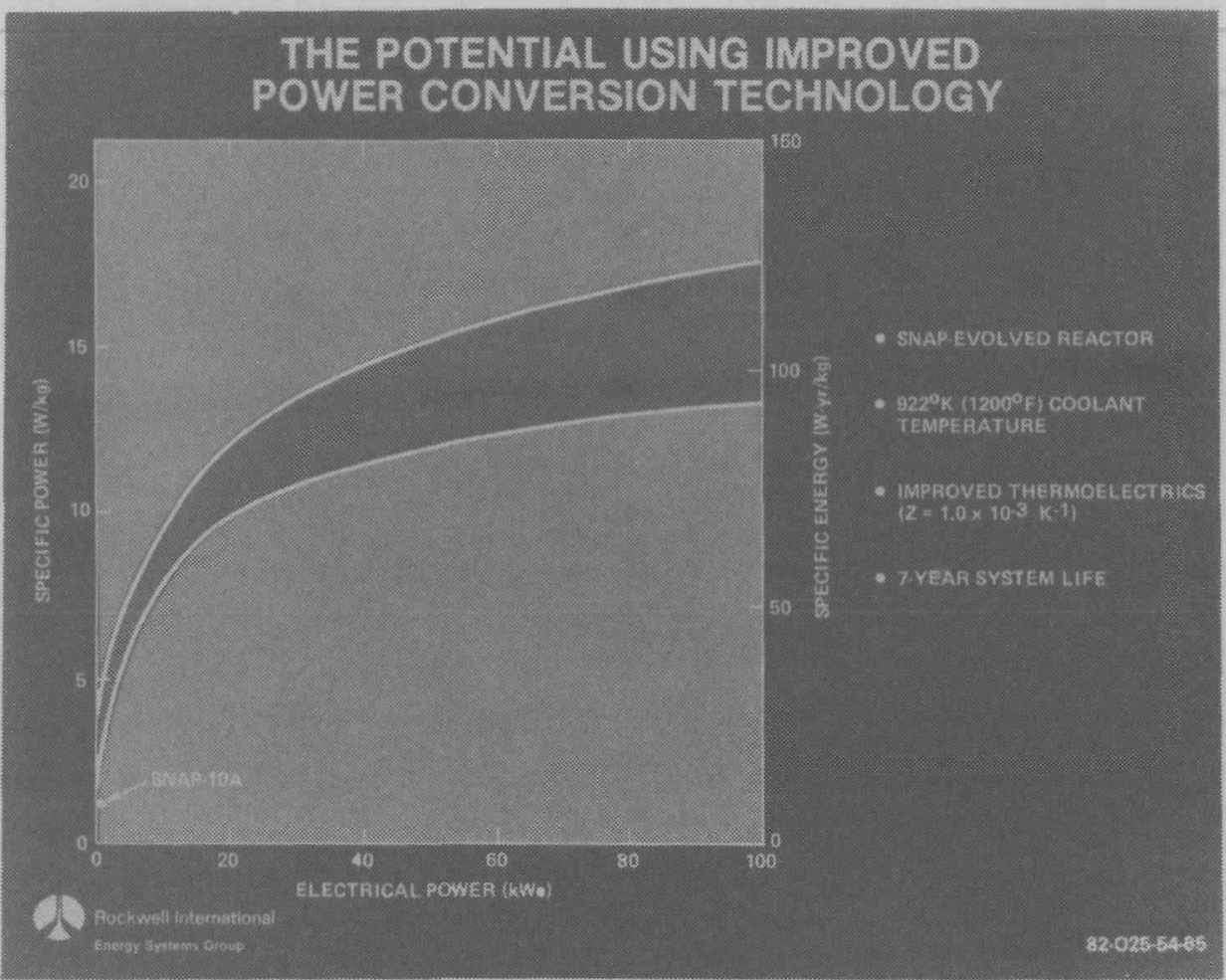

Figure 23

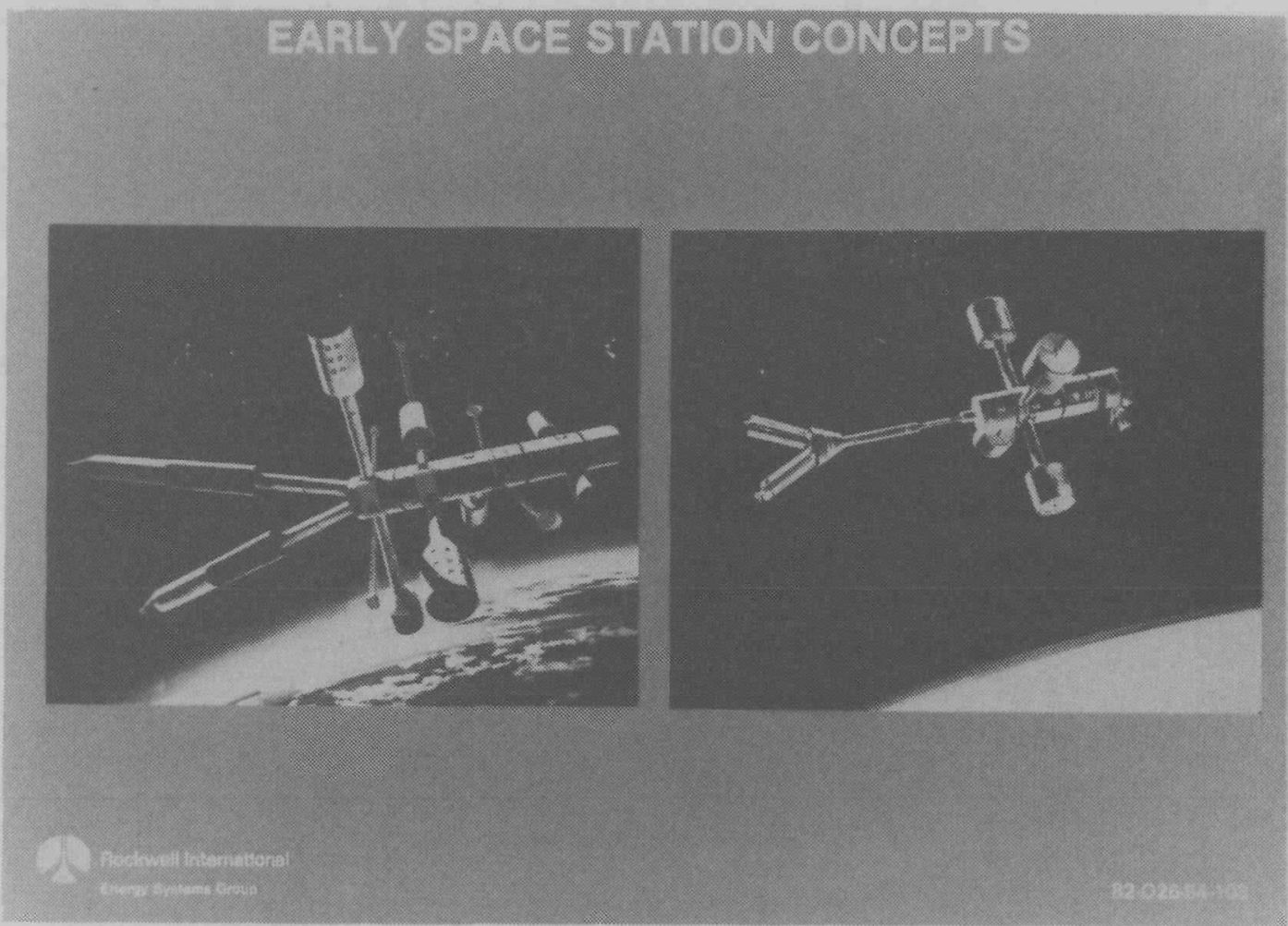

Figure 24 


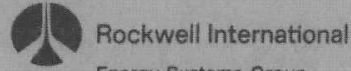 \\ Energy Systems Group}

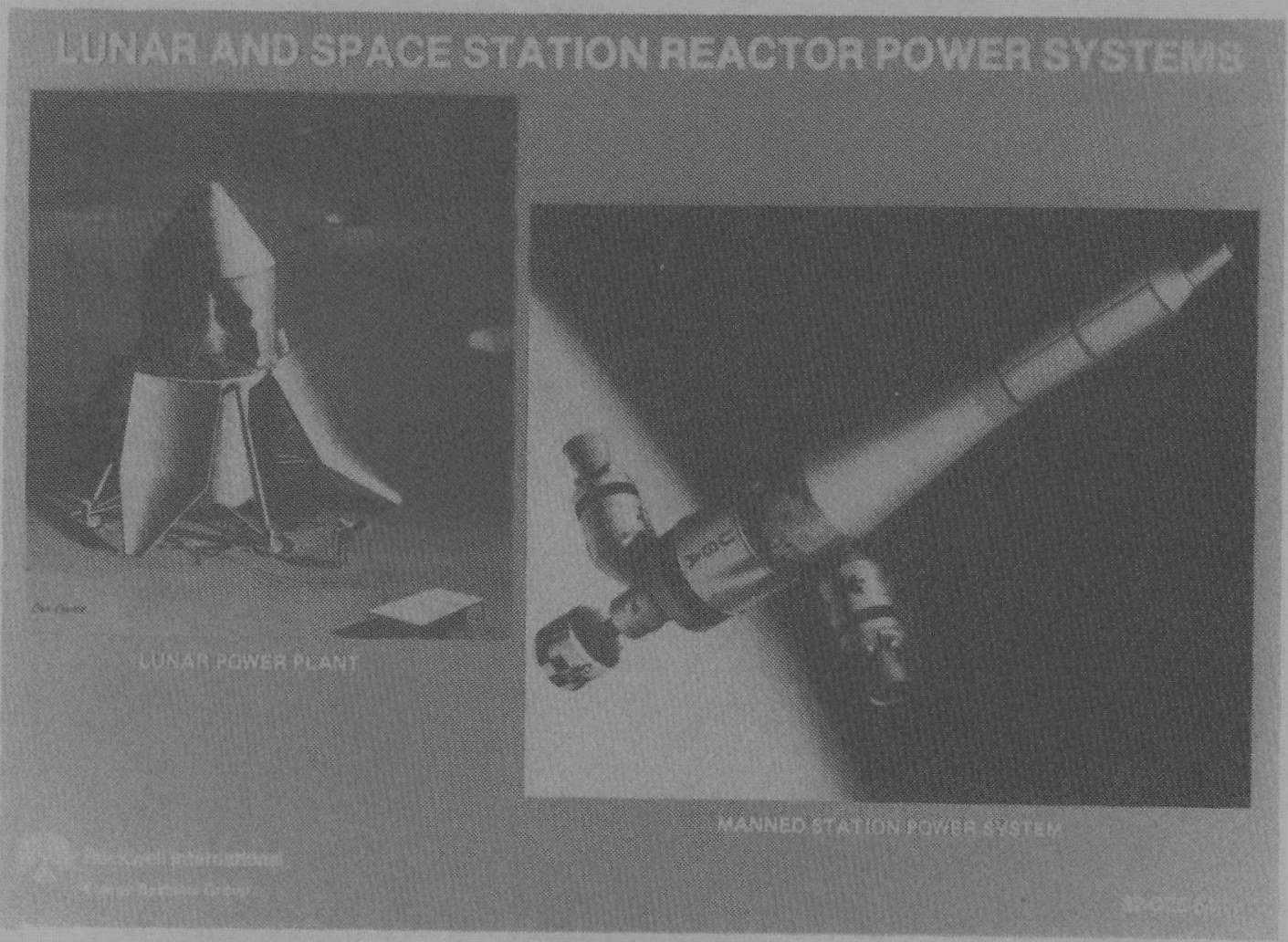

Figure 25

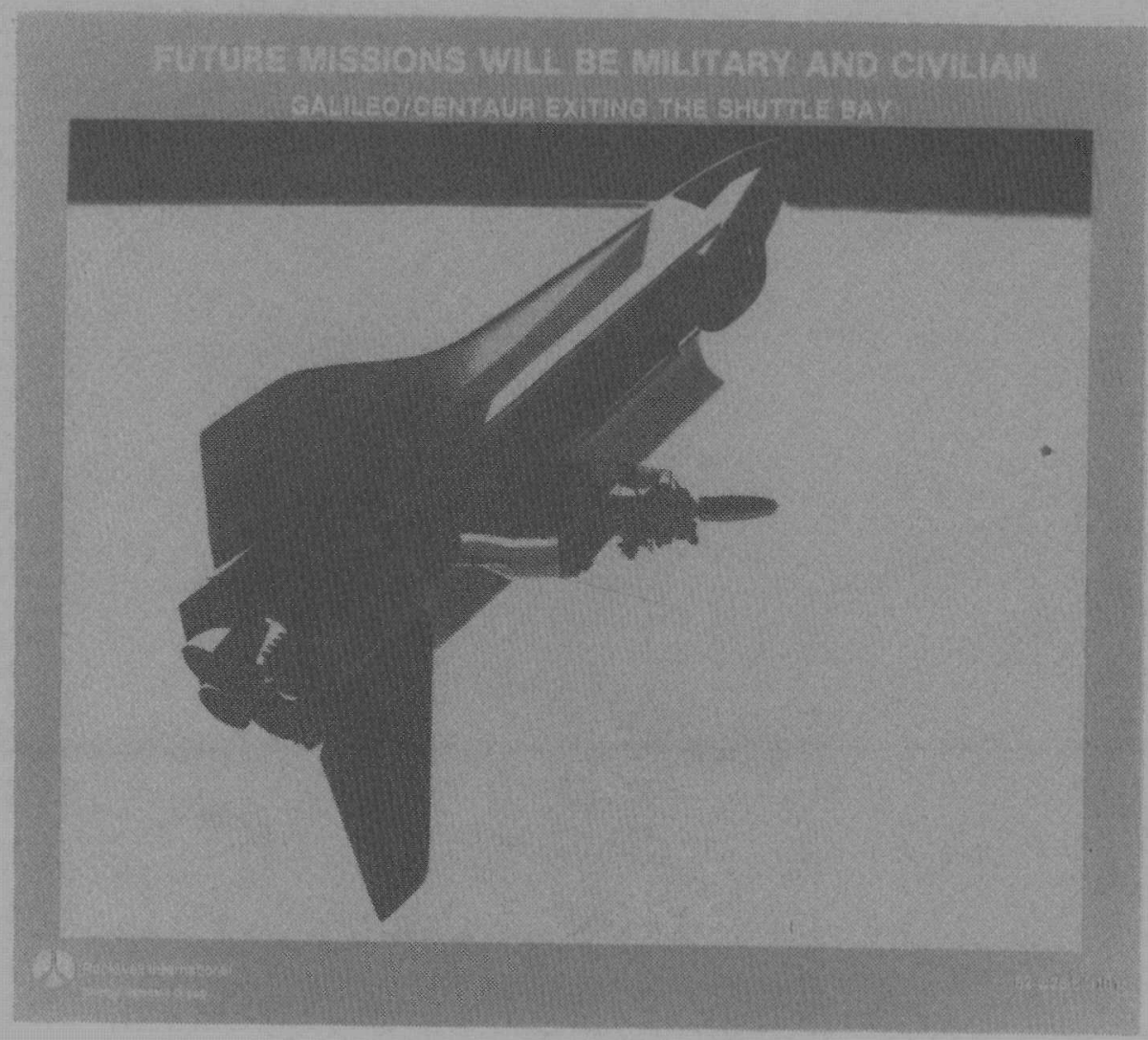

Figure 26 


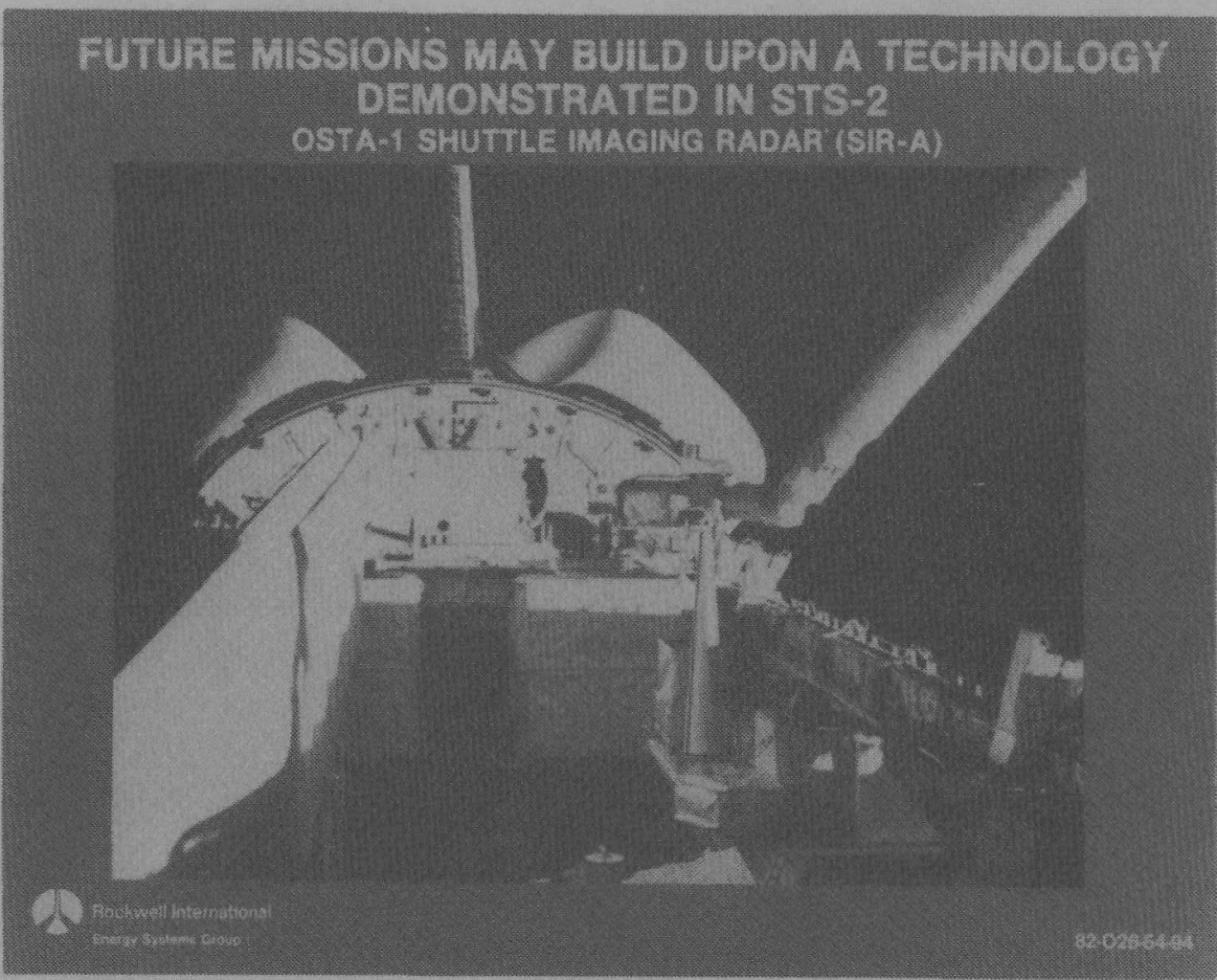

Figure 27

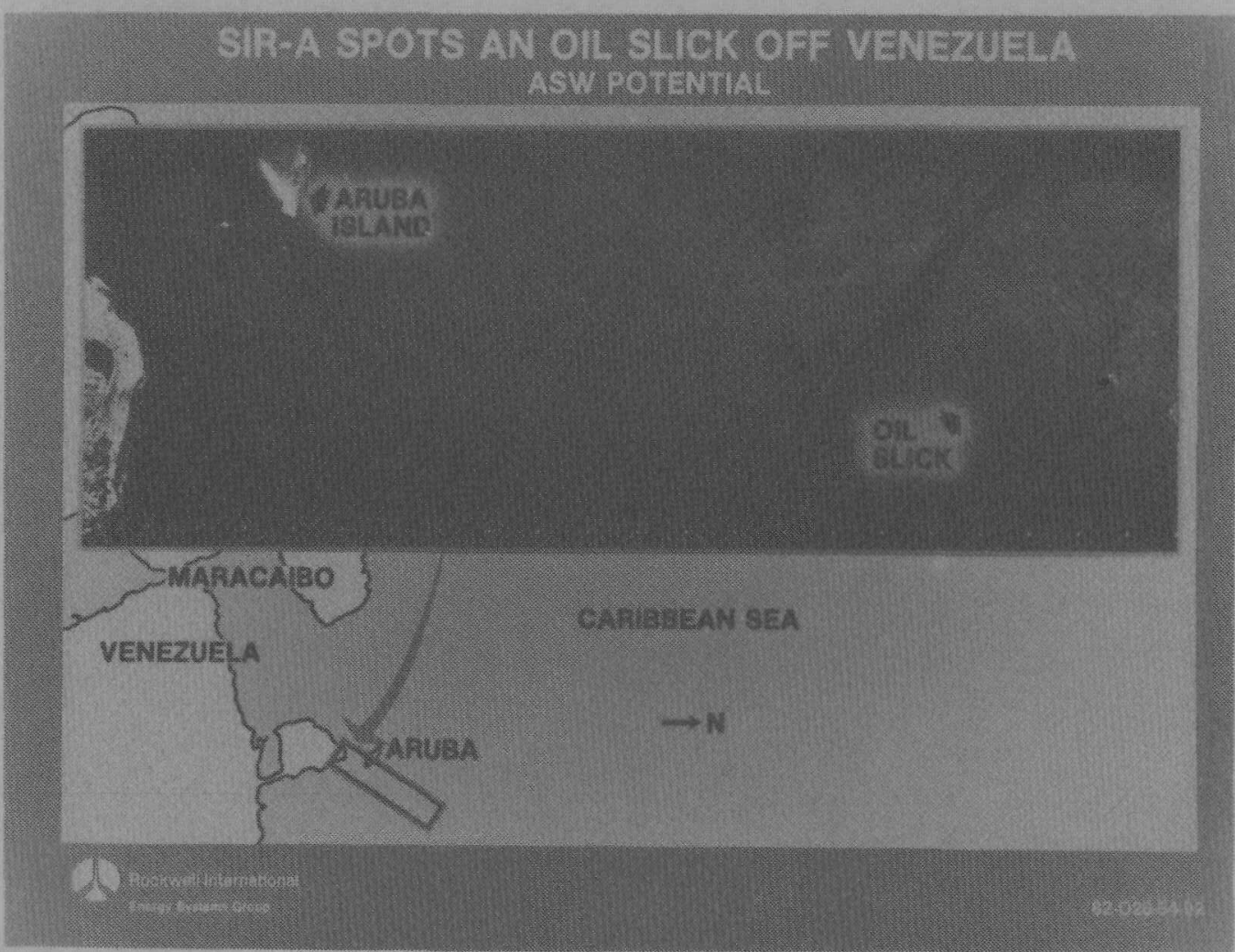

Figure 28 


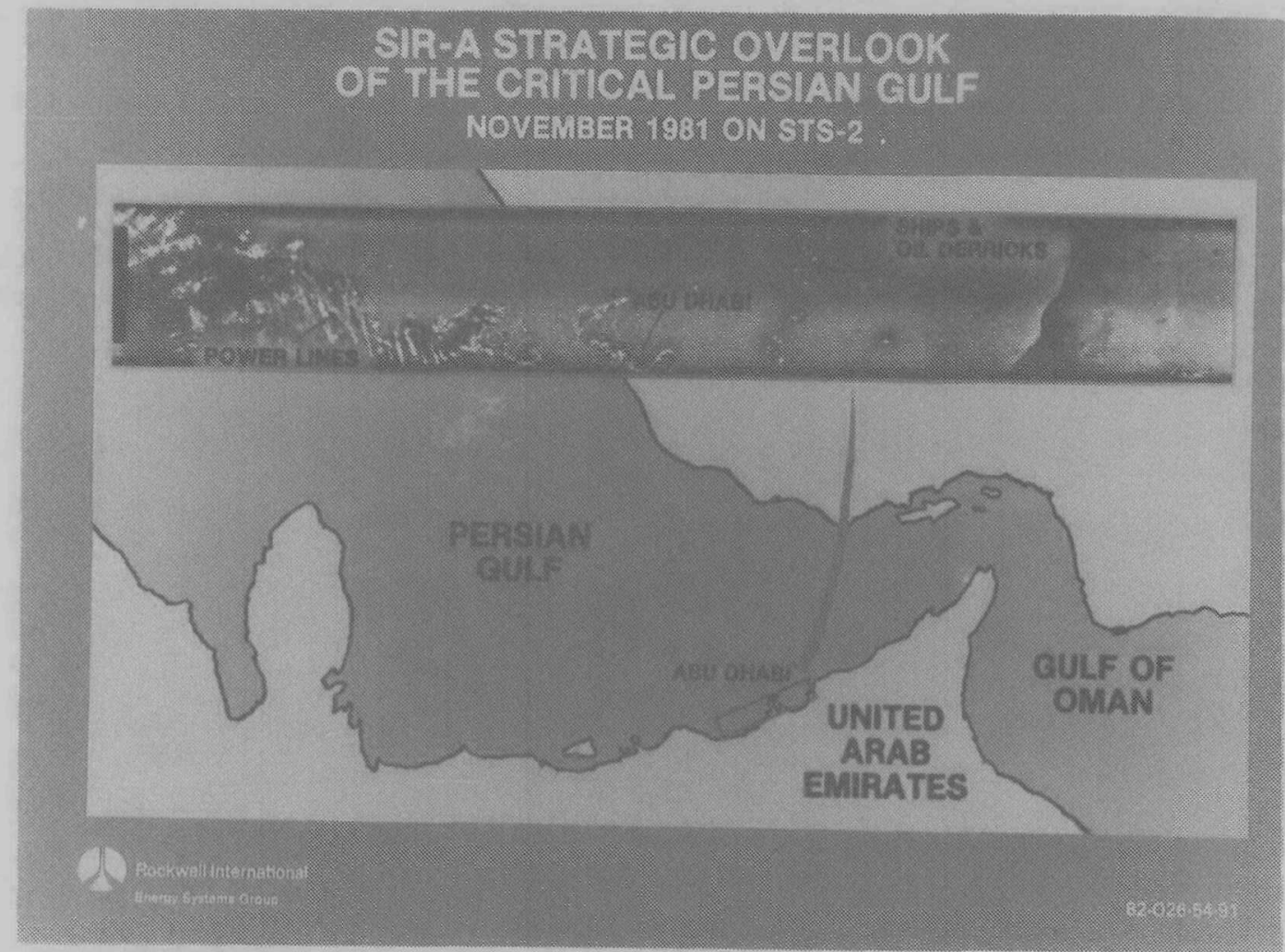

Figure 29

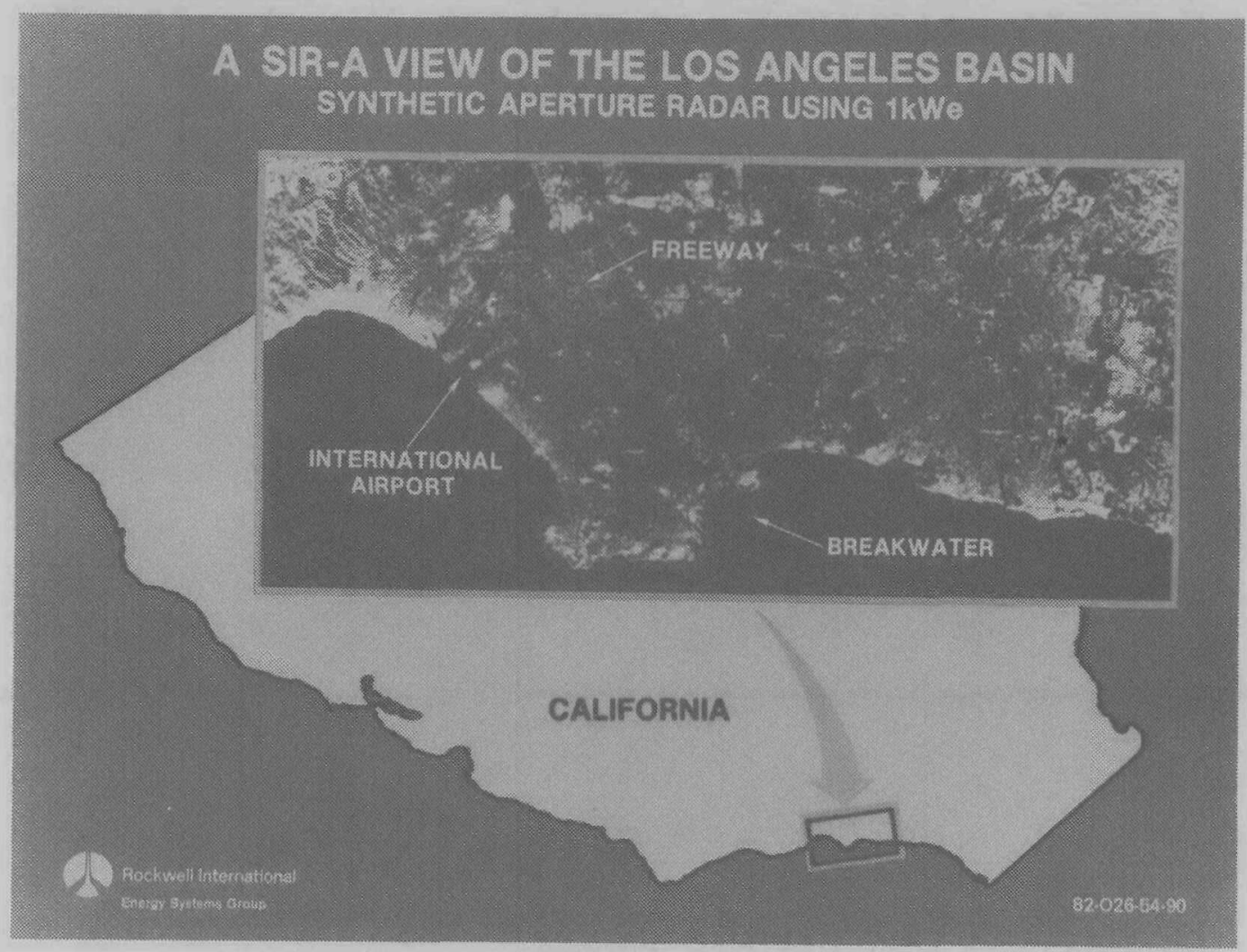

Figure 30 


\section{Rockwell International \\ Energy Systems Group}

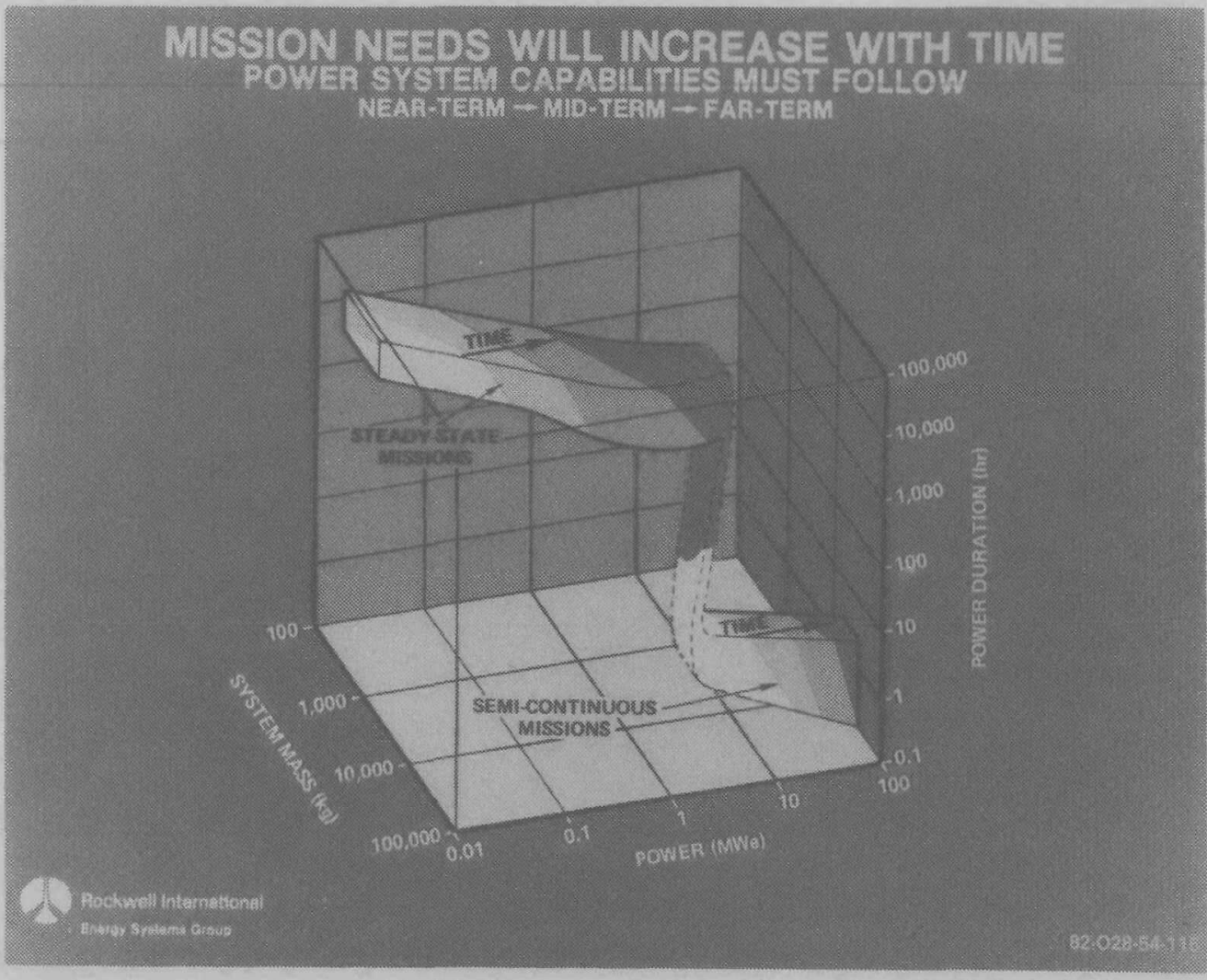

Figure 31

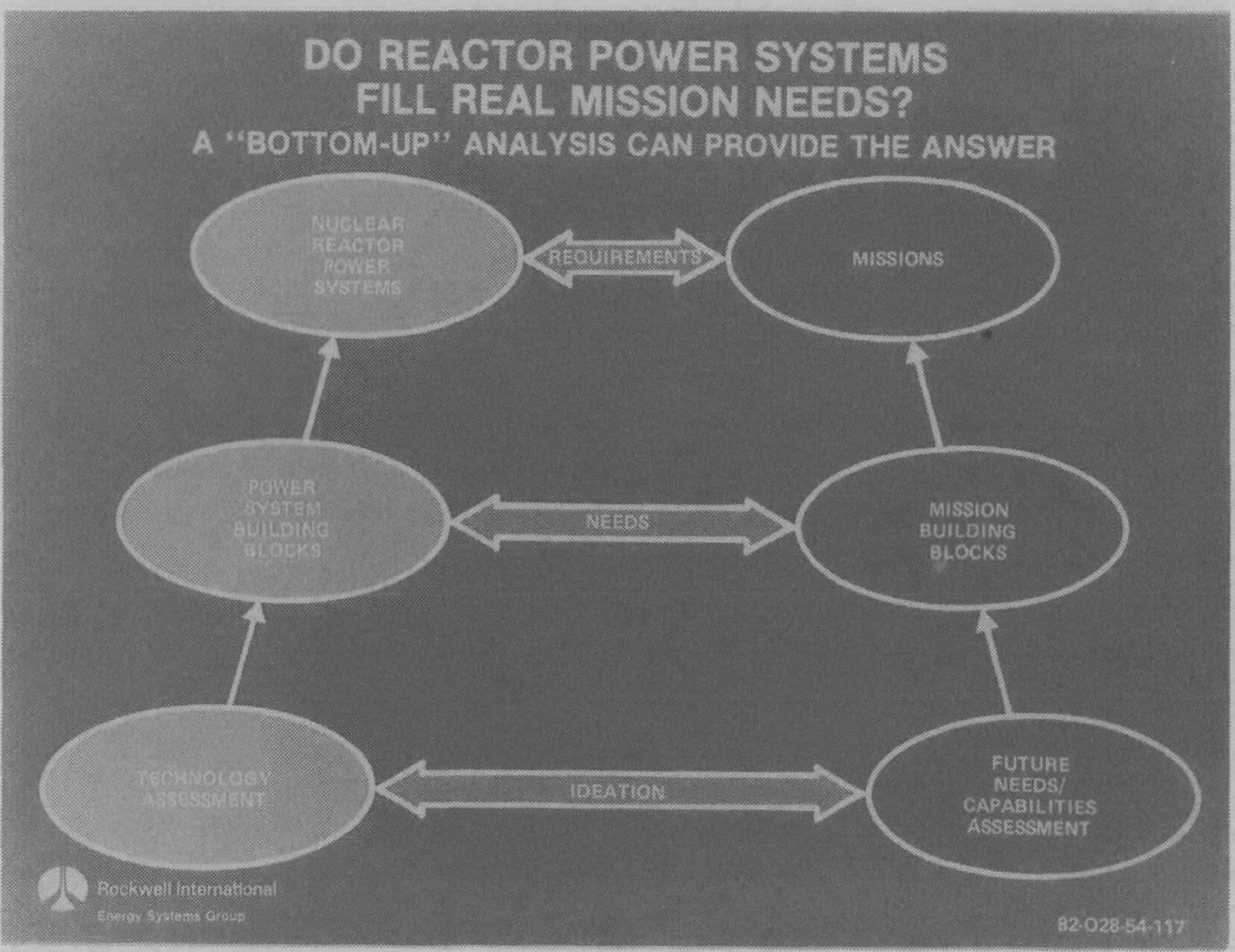

Figure 32 


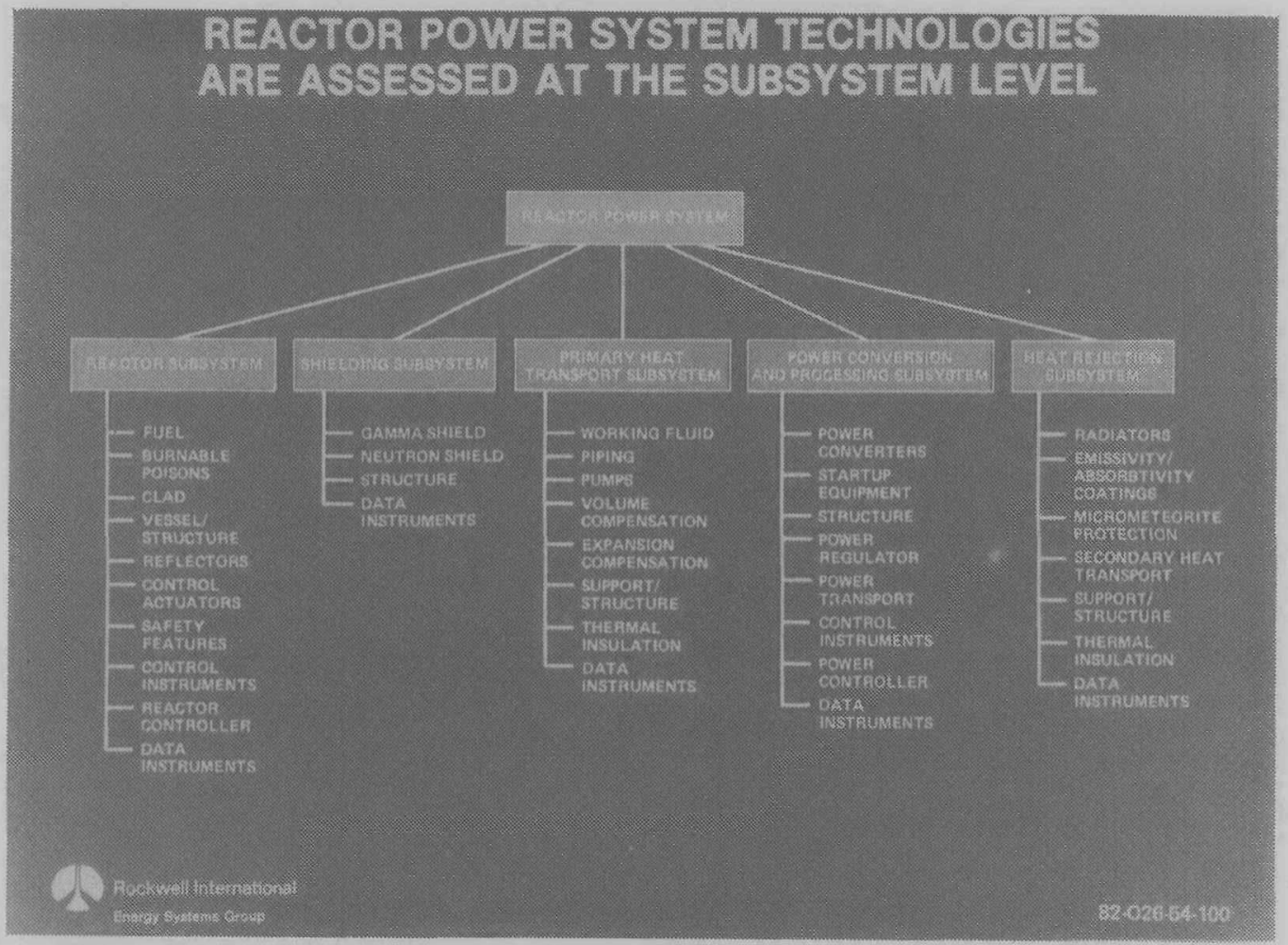

Figure 33

\section{POWER SYSTEM REOUIREMENTS}

MUST BE REPEATEDLY ITERATED WITH THE MISSION
- cost
- SAFETY
- OPERATIONAL DATE
- WaIcuT
- VOL UME
- คOWER L E VEL
- POWER DURATION
- DUTY CYCLE
- STARTUP TME

- POWER RESPONSE

- "SHELF" LIFE

- radiation dosace

- SURVIVABULITYIENDURABILITY

- AUTONOMY

- SICNATURE

- ㅍㄴ.

- REDUNDANCY

- LAUNCH ENVIRONMENT

Figure 34 


\section{A REHCTOR POWER SYSTEMS TECHNOLOGY ROADMAP} IS THE RESULT OF THIS PROCESS

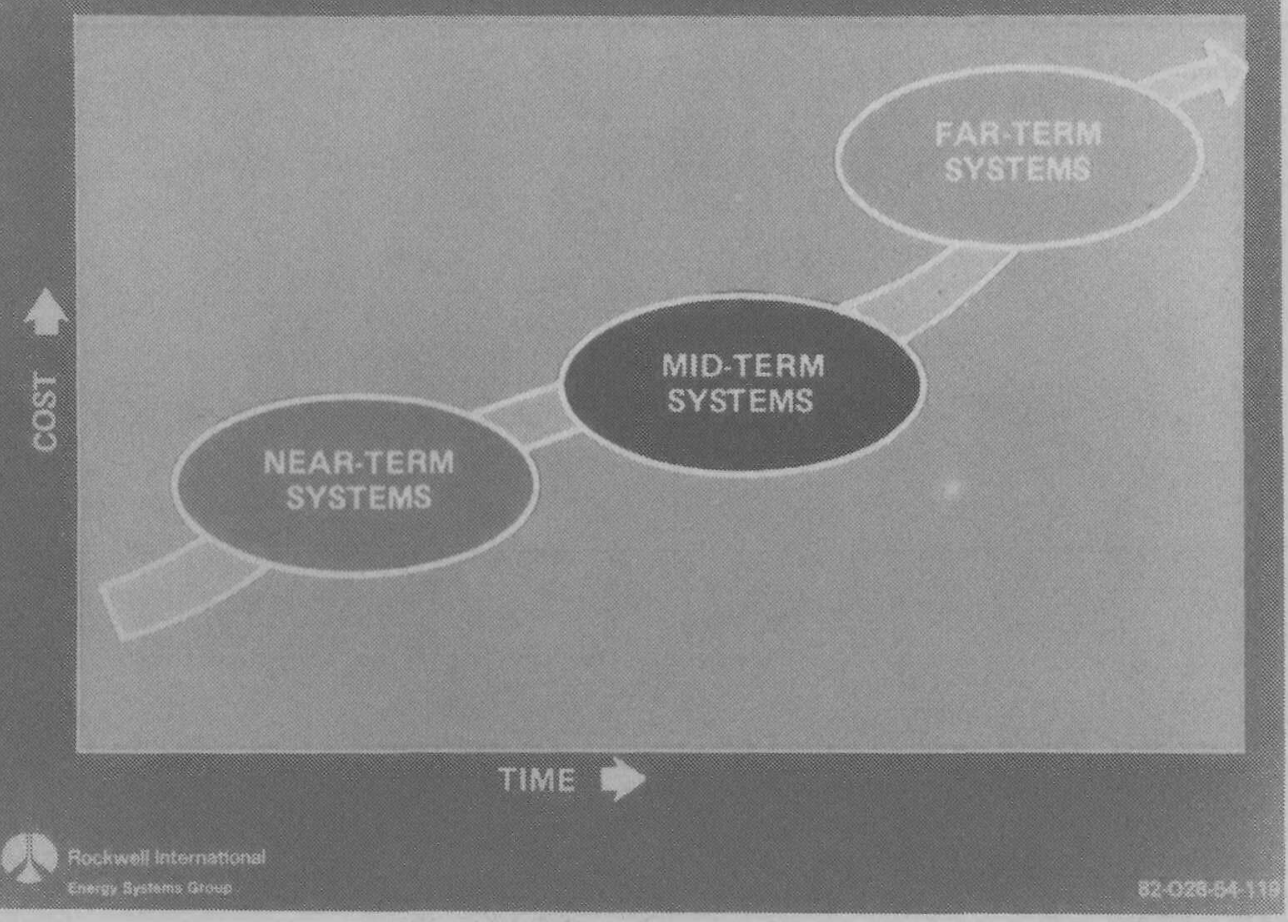

Figure 35

SPACE NUCLEAR POWER

IS NO LONGER TWENTY YEARS AHEAD OF IT'S TIME

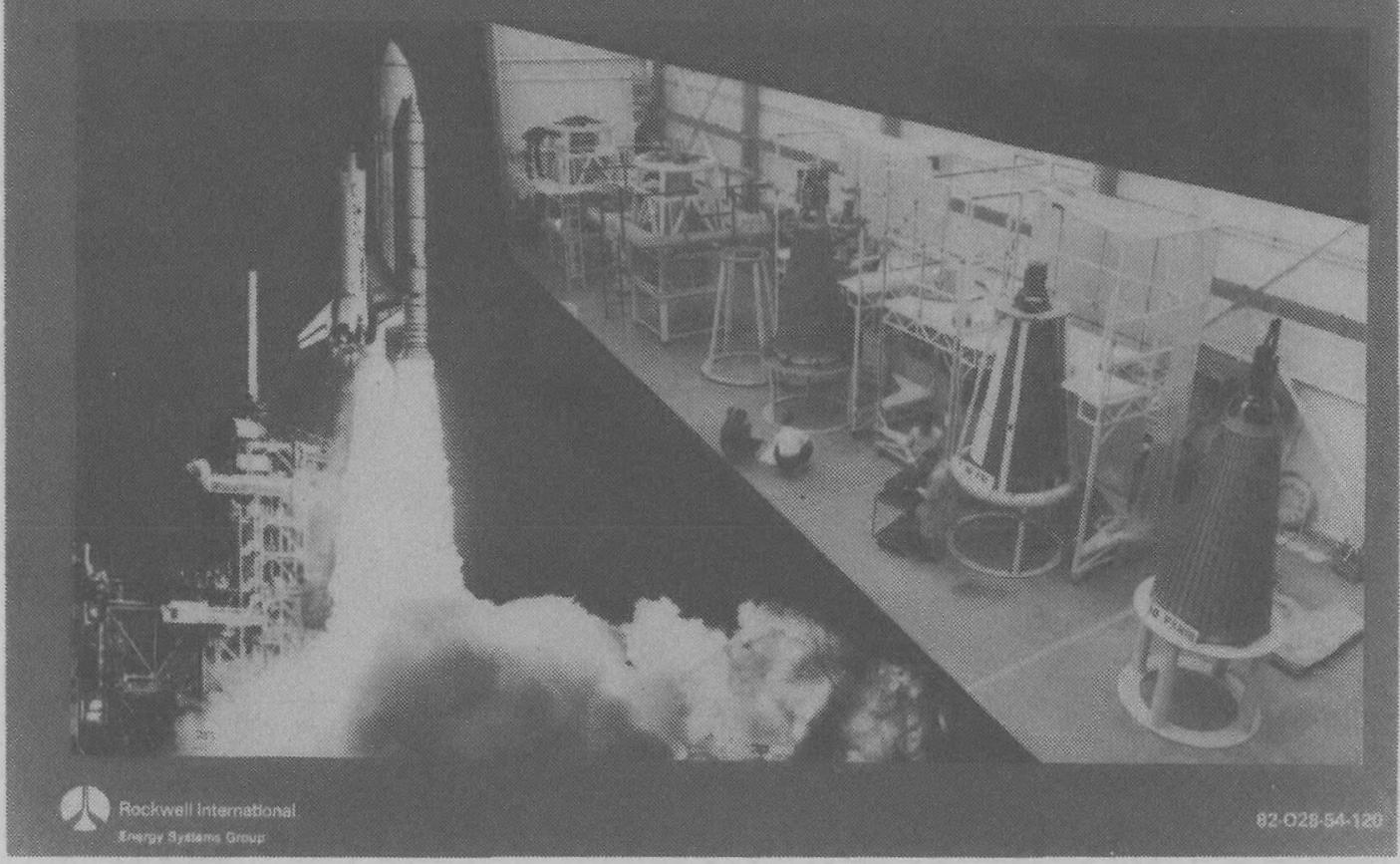

Figure 36 